\title{
ÕPITEKSTI ANALÜÜS KIRJAOSKUSE OMANDAMISE KONTEKSTIS
}

\author{
HELIN PUKSAND, KRISTA KERGE
}

\begin{abstract}
Annotatsioon. Artikkel tutvustab nii teksti- kui ka õpikuasjatundjaid silmas pidades põhikooli õpikukeele uurimusi Tallinna Ülikoolis. Oletatakse, et tekst kui suhtlus- ja tunnetusüksus peaks olema sihtrühmale juba esmalugemisel jälgitav ja üldjoontes arusaadav. Võrreldakse Avita kirjastuse ajaloo- ja muusikaõpikuid (Emakeele Seltsi õpiku-uurimus 2011). Tulemusi kõrvutatakse Helin Puksandi õpiku-uurimusega (2003), mis puudutab ajalugu, loodusaineid ja emakeelt II kooliastmes. Fookuses on õpiteksti kui sidusa teaduspõhise, eluliste tekstidega rikastatud teabeproosa raskusaste, selgus ja sõnavara, mis koos toetavad aine eakohast omandamist ning toimetulekut järjest keerukama ja pikema asjaliku tekstiga. Tekstiparameetrid on valitud nii, et näitajaid saaks varasemate eesti žanriuurimuste toel tõlgendada. Jooksvalt on uuritud tekstiliike, mille kohta võrdluseks vajalikke andmeid ei olnud. Ühtlasi on nii tekstis kui ka joonealustes tegeldud asjakohase terminoloogia ja metoodikaküsimustega, mis on väikekeele puhul oluline. Uurimus näitab õpiteksti raskust suhteliselt sõltumatu, lugemistehnikat tähtsustava faktorina. Nominaalsus ja leksikaalne tihedus moodustavad selguse ja arusaadavuse faktori, millega väljendustäpsust näitav formaalsus tugevasti seostub. Uuritud õpitekst on täiskasvanutekstidest suhteliselt raskem ja vähem selge kahes uuritud õpikus; muusikas tingib seda ka üldkeelekauge erisõnavara. Õpikute aja- ja eakohane kujundus (v.a õpikute lai formaat) kahandab teksti raskusfaktorite mõju. ${ }^{1}$
\end{abstract}

Võtmesõnad: õpikusõnavara, sõnavara rikkus, võõrsõnad, pikad sõnad, nominaalsus ja verbilisus, teksti raskus ja keerukus, teksti ühemõttelisus, kiire ja aeglane tekst, žanriuurimise metoodika, terminikujud

1 Tänu Emakeele Seltsile, kes on õpiku-uurimust toetanud; Eesti Teadusfondile, kelle grandi nr 8605 raames on valitud ja katsetatud uurimismeetodeid, kogutud ja analüüsitud kirjaliku teksti võrdlusandmeid; ning Avita kirjastusele, kes valis ja loovutas õppematerjali nii õpikomplektide kui ka e-käsikirjade kujul. Kirjutise põhiautor on Helin Puksand; Krista Kerge vastutusel on lingvistiline metoodika. Rohkeid allmärkusi on artiklis oluline lugeda vaid õpiteksti teatud aspektiga või terminitega tegeldes. 
Emakeele Selts korraldas 2011. aastal väljaspool üldhariduse (ema)keele ja kirjanduse ainevaldkonda õpikukeele analüüsi. ${ }^{2}$ Tallinna Ülikooli töörühmas kaitses projekti raames bakalaureusetööd Anneliis Annus (2011). ${ }^{3}$

Õpikukeele uurimine on Haridus- ja Teadusministeeriumi keeleosakonna vastutusalasse jääva eesti keele arengustrateegia üks neid tegevusi, mis peaks tõhustama eesti keele õpet üldhariduskoolis laiemalt. Nimelt omandatakse emakeel ja hariduskeel (kooli aspektist õppekeel) ning funktsionaalne kirjaoskus kokkupuutes tekstidega. Õppekeele, sh kõigi aineõpikute tähtsus selles on suhteliselt suur. ${ }^{4}$

Rahvusvaheline lugemisühing on tosin aastat tagasi üle maailma teadvustanud, et kõik õpikud peaksid kaasama võimalikult palju autentseid tekstiliike, mis ei ole loodud spetsiaalselt õppimiseks (vt IRA 1999). Sama mõtet arendab nii kirjaoskuse kui ühiskonna teatavate tavade-harjumuste kogu (ingl social practice) tähtsustamise üldine ideoloogia (nt Johnson, Kress 2003) ${ }^{5}$ kui ka olukohastatud harjutamise õppeviis (ingl situated practice). Keele ja kõneaine üheaegset omandamist koolitöös nähakse elulistele olukordadele tugineva kogemuse teadvustamise, läbiarutamise ja kriitilise raamistamisena (ingl critical framing). Just selline sotsiaalset praktikat ja individuaalset kogemust ühendav (sotsiokognitiivselt orien-

2 Tartu Ülikool keskendus Koolibri kirjastuse õpivarale (Kärt Talsi, Keemiaõpiku loetavuse analüüs. Ettekanne „Tekstipäeval 2011”) ja Tallinna Ülikool Avita kirjastusele. Tulemusi tutvustati ühisel konverentsil „Tekstipäev 2011" Tartu Ülikoolis (20.01.2012), mille avapool oli pühendatud just haridusvaldkonna tekstide analüüsile.

3 Rühma kuulusid bakalaureuseõppe üliõpilased. Anneli Annuse uurimuse (2011) ja Mari-Liis Sooviku eeltööde andmevalikut, arvutusi ja tõlgendusi on artikli autorid parandanud ja mitmes suunas arendanud. Krifiti Känd alustas uurimust pärast siinse artikli valmimist. Õpikute sõnastuse kvaliteet on artiklis kõrvale jäetud, seda uuritakse võimaluse korral eraldi.

4 Vt nt Maanso 1979, 1981, 1982; Mikk 1979, 1980, 1991, 2000, 2003; Priimägi jt 1979; Puksand 2003, 2004, 2005; Kerge 2002b; Kerge, Uusen 2010.

5 David Johnson ja Gunther Kress (2003) arutlevad kirjaoskuse kontseptsiooni ja hinnatavuse üle ühiskonna mitmekesistumise ajajärgul, nn uue majanduse ja üleilmastumise taustal. Kirjaoskust selle tasemetega aga tajutakse juba majandustegurina ka majandusteaduses (vt nt Alok Bhargava, Globalization, Literacy Levels, and Economic Development. Working paper RP2008/04. World Institute for Development Economic Research; http://ideas.repec.org/p/unu/wpaper/rp2008-04. html). 
teeritud $^{6}$ ) õppetöö peaks esile tõstma seosed keele ja mõtte, arusaamiste ning vahetu ja avarama konteksti vahel, s.o tekstide ja mõistmiskonteksti koostoime. (Kern 2000: 133; pikemalt Gee 200477) Aja- ja eakohane õpivara on üks selle õppeviisi aluseid ja komponente.

Teisalt on kirjaoskuskogemuse kasvuks oluline teadvustada tekstide loomise ja vastuvõtu eripära ning seoseid - need protsessid põimuvad tekstide ja inimeste interaktsioonis, s.o suhtluse ja tunnetuse käigus, nagu see on omane ka õppimisele. Üldhariduskoolis omandatakse oskus keelt asjalikult kasutada - s.o mõista, vahendada ja luua tekste. Ühtaegu mitmekesistub õpiaja tekstikogemuse kaudu keelepagas: nii teema- ja žanrikohane üld- või erisõnavara ja grammatika kui ka sagedasim ning kõikjal vajalik keeleaines. ${ }^{8}$ Osates eri tüüpi tekstidega töötada, osatakse omakorda ka õppida: omadel eesmärkidel kuulates või lugedes mõista ja mõistes toimida; kirjutades või kõneldes kuuldut-loetut vahendada; reageerida kirjalikule ülesandele teksti või muu tegevusega, arvestada samas ülesandesse kaasatud näidet; mõistmise ja mõistva kirjutamise jaoks vajalikku suuliselt küsida või kirjalikke andmeid leida, võrrelda ja kontrollida; alusandmeid tabelist ja jooniselt välja lugeda või järelduvat nende kujul väljendada jne (vt nt Gee $2008^{9}$ ).

Emakeel on seega kõigi ainete õppimise alus ja koolihariduse eluline eesmärk. Põhikooli riiklik õppekava (PRÕK 2011) seabki sihiks nii õpikui ka suhtluspädevuse ${ }^{10}$ ja avab neid suuresti just kirjaliku keelekasutuse osaoskuste kaudu, mida osaliselt tagavad õpikud. Kõik mainitu sõltub

6 Vt Kerge 2011c.

7 Keeleõppe kontekstis on neid teemasid vahendanud Kerge (nt 2011a, 2011b, 2011c).

8 Heiki-Jaan Kaalepi ja Kadri Muischneki (2002: 14-15) järgi katab 3000 sagedasimat sõnavormi 64\% ja 3000 sagedasimat sõna u 81\% eesti kirjakeele korpuse ajakirjandus- ja ilukirjandustekstidest, mis on olnud nende sagedussõnastiku aluseks. Suur tähtsus on muu hulgas funktsioonisõnadel kui grammatika osal. Haritud emakeelekasutaja asjalikus tekstis on 3000 sagedasima sõna osatähtsus Hille Pajupuu jt (2009) järgi u 66\%.

9 Eesti keele kohta vt Kerge 2008a ja 2008b tekstitöö peatükki või Kerge 2011a, 2012 b ja 2012c.

${ }^{10}$ Nimetatud pädevused on fikseeritud õppekava $\S 3$ lõigetes 4 ja 5. Eesmärgiks on seatud muidki keeleoskusega seotud pädevusi (nt sotsiaalne pädevus ja isegi enesemääratluspädevus). Õppekava lisa 1 tõdeb: „Keel on rahvuskultuuri ja rahvusliku identiteedi kandja ning tema valdamine kõnes ja kirjas on inimese mõtlemisvõime kujunemise, vaimse arengu ning sotsialiseerumise alus ja eeldusi." 
omakorda sellest, millised on õpikute tekstid - vastus on seda tähtsam, et uurimiseks valitud ajaloo ja muusikaõpetuse puhul ei ole tavakooli õpiraskustega eesti laste jaoks erivahendeid ega -soovitusi (vt Henno 2011).

Paljud tekstitöö vahendid (s.o tekstiteadlikkuse kui metatasandi) tagab emakeeleõpetus, kuid selle aine rolli siin ei puudutata. Tekstiõpetusel on 1996. aastast olnud eesti emakeele ainekavas keskne osa. Uues õppekavas (PRÕK 2011) on kogu aine tekstikeskne.11 15 aasta õppekogemus peaks emakeeleõpetajatel lubama värske suunamuutusega kiiresti harjuda ning tagama õppijale muudeks aineteks vajaliku taustapagasi.

\section{Uurimused eesti õpivara keelest ja tekstidest}

Õpivara ${ }^{12}$ ilmub üldhariduskoolile pidevalt. Iga riikliku õppekavaga uuenevad õpikomplektid suurel määral, arvestades nii kava üldist ideoloogiat, ainete kooslust ja seoseid, taotletavaid pädevusi, läbivaid teemasid jm komponente kui ka kindla aine õpetamise eesmärke, õpisisu ja oodatavaid tulemusi. Õpikuautoril tuleb silmas pidada ka aine jaoks õppekavas kehtestatud tundide arvu. Õpikomplekte värskendatakse üha tihemini, sest isegi iga juurdetrükk lubab vahetada mõne osa uue vastu. ${ }^{13}$

Õpikute keeleline külg on olnud maailmas uurimisobjekt, mida seostatakse eakohasuse jm didaktilisega, kuid ka tekstide valikuga ning nende ideoloogia ja vastuvõetavuse mitmesuguste tahkudega (selgus, mõistetavus, kultuuri, soo vm identiteedirühma eksplitseerimise viis jne). Õpikute keelt on Eestis uuritud suhteliselt palju. Näiteks on Jaan Mikk juba üle

11 2011. a õppekava sisu toetavad artiklid aineraamatutes: veebilehelt www.oppekava. ee leiab lingi nii põhikooli kui ka gümnaasiumi valdkonnaraamatule „Eesti keel ja kirjandus" (vt nt Kerge 2010b, 2011a, 2011b, 2011c; Puksand 2010c).

${ }^{12}$ Kas rääkida õppe- või õpivarast, õppe- või õpivahendist, õppe- või õpitekstist, oleneb pedagoogikaarusaamadest - varem rõhutati õpetamist, nüüd pigem õppimist (aine omandamist dialoogis õpitekstide, õpetaja ja õpikaaslastega). Õppijakesksus, sh lapsesõbralikkus, tähendab ka vastutuse nihkumist õpetajalt õppijale. Teisalt ei ole põhjust üldkirjakeeles juurdunud sõnu õppematerjal, óppetöö jne tingimata välja vahetada.

${ }^{13}$ Ühiskondlike muutuste kiiruses on teatava piirini tähtis õpikutekstide aktuaalsus kui üks huvi äratamise teguritest. Helin Puksand kui õpikuautor tõi tekstipäeval värskeid näiteid käibiva õpiku teksti ning sellega seotud ülesannete operatiivsest väljavahetamisest õpikomplekti uues trükis. 
kolmekümne aasta tagasi kirjutanud, et õpikuteksti keerukust saab hinnata selle mitut komponenti uurides, sest ühe komponendi järgi pole võimalik saada täielikku pilti. Tulemuste tõlgendamisel soovitab ta arvestada, et teksti liigne lihtsus kahjustab õpilaste väljendusoskuse arengut. Õpikutekst peab ideaalis oma väljendusrikkuse ja täpsusega andma õpilastele eeskuju, kuid samal ajal olema hästi mõistetav. Nõnda saab õpilane teadlikult omandada nii edasiantava sisu kui ka selle väljendamise vahendid. Kõige edukamalt arendab õpilaste väljendusoskust optimaalse keerukusega tekst, mis sisaldab õpilastele uudseid sõnu, keelendeid ja fakte õpilastele mõistetaval määral. (Mikk 1979) Rohkete uurimuste ja kirjutiste kaudu, mille põhi- või alateemaks on õpiteksti keerukus või õpilaste oskus end väljendada ja teksti mõista (nt Mikk 1980, 1991 jm¹4), on Mikk jõudnud põhjaliku ja maailmas palju viidatud õpikukäsiraamatuni ${ }^{15}$, mis on avaldatud Saksamaal (Mikk 2000). Püsivalt on osutatud õpiku raskusastme korrelatsiooni lausete ja sõnade pikkusega (nt Mikk 1980; Elts 1995; Mikk jt 2001 jm). Mikk (1980: 78) on isegi tuvastanud, et keerulisema õpikuga ainetes on edasijõudmatus suurem.

Viivi Maanso (1979, 1981, 1982 jm) on uurinud õpikute võõrsõnalisust, pikkade sõnade osatähtsust jm, mis sisule keskendumist segab. Ta on leidnud, et mida noorem on laps ja mida väiksem tema lugemisoskus, seda rohkem põhjustavad pikad sõnad takerdumist. Halb lugeja suudab ühe pilguga haarata vaid 3-4 tähte, hea lugeja 8-10 tähte ja üksnes kiirlugeja 13 või enam tähte. (Maanso 1982) Ka Keith Rayneri jt (2001) andmetel on silmaliigutuse keskmine ulatus 7-9 tähekohta. ${ }^{16}$ Õpikute võõrsõnu on oma lõputöös uurinud ka Margit Raik (2001).

Koos on V. Maanso ja J. Mikk (1979) õppeteksti käsitlema ärgitanud teisigi autoreid, kuid nende enda arutlused õppimise ja teksti üle

${ }^{14}$ Jaan Miku tööde ülevaatest http://raud.ut.ee/ jaanm/publikatsioonid.htm (25.01.2012) on näha, kui palju ja kui mitmes keeles on ta avaldanud töid õpikukeele analüüsist ja teksti mõistmisest.

${ }^{15} \mathrm{~J}$. Miku nimetatud raamat on rahvusvahelise õpikute ja haridusmeedia uurimise ühingu (International Association for Research on Textbooks and Educational Media, IARTEM) kodulehe raamaturubriigis ainuke viidatud teos; viitele on lisatud kiitev tutvustus Georg R. Klare'ilt (vt http://www.iartem.no/books.html).

${ }^{16}$ Ühe silmaliigutuse mõõt on ingl saccade (short rapid movement) 'sakaad', mida piiritlevad fixation'id ('fikseerimine, kinnitamine'). Vt ka Keith Rayneri ja Monica Castelhano selgitusi aastast 2007 ja tabelit 1 lingil http://www.scholarpedia.org/ article/Eye_movements (20.02.2012). 
pole lakanud ega oma aktuaalsust kaotanud (vt Mikk 2003). Hiljuti on Reili Argus avaldanud Õpetajate Lehes arvamust, et õpikute keel ei ole eakohane, ning osutanud näidete toel, et sellele võib veel mõndagi ette heita (Argus 2011). Nii võib oletada, et Emakeele Seltsi algatus on aktuaalne.

Siinkirjutajatel on õpikukeelega erinev suhe. Helin Puksand (2003) on detailselt võrrelnud Avita ja Koolibri kolme aine IV-VI kl õpikomplekte (vt „Materjali allikad”) ning avaldanud osa tulemusi kahes artiklis - ühe teema on õpikuteksti keerukus ja teise oma sõnavara (Puksand 2004, 2005). Muu kõrval uuris ta (ibid.) sama astme õpetajate rahulolu õpivaraga. $80 \%$ õpetajaid oli täiesti või enam-vähem rahul õpikute terminimääraga ja $85 \%$ arvas, et termineid on alati või peaaegu alati piisavalt seletatud. Samas sai vaid kolmandik õpetajatest õpikomplekte ise valida ning veerand kasutas rööpselt ka vanu õpikuid, tuues muu hulgas põhjenduseks, et nende ülesanded on lastele arusaadavamad, tekstid lihtsamini sõnastatud ja õpilasele jõukohased ning sobivad ka iseseisvaks õppimiseks (Puksand 2003: 2. ptk).

Ühtlasi on H. Puksand vastutanud PISA 2009 Eesti uurimuses ${ }^{17}$ lugemisoskuse osa eest, analüüsinud eesti õpilaste lugemuse laadi ja nende enesetaju lugeja rollis, võrreldes olukorda Soome avaramas uurimuses $^{18}$ leituga, ning vaaginud seoseid PISA tulemuste ja teismeliste lugemisharjumuste vahel (vt Puksand 2010a, 2010b, 2011, 2012 ilmumas). ${ }^{19}$

${ }^{17}$ PISA (Program for International Student Assessment) on OECD ülemaailmne 15-aastaste õpilaste hindamise programm, mis keskendub õpilaste põhioskuste mõõtmisele lugemise, loodusteaduste ja matemaatika valdkonnas. Eesti on osalenud 2006., 2009. ja 2012. a uurimuses; 2009. aastal oli põhivaldkonnaks funktsionaalne lugemisoskus.

${ }^{18}$ Vt Minna-Riitta Luukka, Sari Pöyhönen, Ari Huhta, Peppi Taalas, Mirja Tarnanen, Anna Keränen, Maailma muuttuu - mitä tekee koulu? Äidinkielen ja vieraiden kielten tekstikäytänteet koulussa ja vapaa-ajalla. Jyväskylä: Jyväskylän yliopisto, 2008.

${ }^{19}$ Helin Puksandil on Tartu Ülikooli diplom eripedagoogika alal ja teadusmagistrikraad eesti keele alal Tallinna Ülikoolist, kus ta töötab õpetamise aluste lektorina. Tal on ka suur õpetajastaaž ning ta on eesti keele õpivara autoreid (põhikooli eesti keele ja meediaõpetuse õpikud, töövihikud, kontrolltöökogumikud jm). Vt nt Helin Puksandi, Reet Bobõlski jt 2011. a õpikomplektide „Sinasõprus keelega” ja „Peegel” tutvustusi Koolibri või raamatupoodide kodulehel. 
Krista Kerge on uurinud žanreid. Tekstikeerukuse andmete toel on ta vaaginud õpitekstide lapsesõbralikkuse tagajärgi: kooliaja tekstide suhtelise lihtsusega võetakse risk, et ülikoolis ja tööl ees ootavate väga palju keerukamate tekstiliikidega on raske toime tulla (vt Kerge 2002b).

Oma kogemuse toel üritatakse kõigi eelviidatud seisukohtadega allpool ka arvestada.

\section{Teoreetiline raam, materjal ja metoodika}

Õpiteksti vastuvõtt on kirjaoskustoiming, täpsemini kognitiivselt kompleksne lugemistoiming (vt nt Israel jt 2005). ${ }^{20}$ Kuivõrd vaatluse all on emakeeleainest väljapoole jäävad õpikud, siis tekib küsimus, mis on ainevaldkonna kirjaoskus - nt kirjaoskus muusika, looduse, ajaloo vm valdkonnas. On selge, et igas aines on kirjaoskuse aluseks valdkonnateadlikkus. Samas on inimene läviv olend. Nüüdses sotsiokognitiivses ehk ühtaegu indiviidi ja tema elukeskkonda arvestavas arusaamises seostuvad sel moel aine- ja suhtluspädevus: ainevaldkonna kirjaoskus on suutlikkus mõista ja luua selle valdkonnaga seostuvaid tekste. Seega ei ole nt muusikaline kirjaoskus mitte mõne õpetaja praktikas eesmärgiks seatud võime nooti lugeda, vaid oskus muusika asjus kommunitseerida, millel on nii muusikatundmise kui ka tekstilise suhtluse tahk. ${ }^{21}$ Teadmised liiguvad seega moode- ja spiraalepidi, kuid jõuavad tuttavasse, ehkki uuel viisil läbitunnetatud punkti (vt Miku eeltoodud 1979. a arutlusi õpikute kaheplaanilise funktsiooni üle).

Pirjo Karvonen (1995) on avaldanud olulise õpikutekstikäsitluse „Oppikirjateksti toimintana” („Õpikutekst kui toiming”). Oma doktoritöö toel vaatleb ta geograafia ja bioloogia õpikuteksti kui kommunikatiivset akti. Kindlate registritunnustega õpikutekst ${ }^{22}$ peaks tema järgi siduma teadusliku diskursuse igapäevatekstide omaga, nt terminid arusaadavate selgitustega, ja pakkuma erisõnavara mõisteliigitelude ehk taksonoomiate

\footnotetext{
${ }^{20} \mathrm{Vt}$ ka arutlusi artikli sissejuhatuses.

${ }^{21}$ Häid artikleid leiab otsingutega musical literacy, environmental/ecological literacy jms. Ajalookirjaoskuse teemal on suurepärane mitmetahuline $41 \mathrm{lk}$ käsitlus veebis; vt Historical literacy. Australian Government. Department of Education, Science, and Teaching. The National Centre for History Education; http://www.hyperhistory. org/images/assets/pdf/literacy.pdf (20.01.2012).

${ }^{22}$ Vt mõistekäsitlusi ja allikaid Karvonen 1995: 22-24, 33-43, 165-196 jm.
} 
osana. ${ }^{23}$ Selline tekst on ühtaegu kultuurisidus ja kannab kindlat ideoloogiat kahes plaanis. Ideoloogia avaldub õpiku teemavalikus ja ainemõistmises - mis teadmisi pakutakse ja milline sisu või orientatsioon on neile antud $^{24}$-, kuid ideoloogia ilmneb ka teadmiste esituslaadis, teadmiste omandamise, kinnistamise ja kordamise viisides, mida õpik pakub kuidas õppimist mõistetakse ja kuidas see õpikutekstis ilmneb. Esimene plaan, n-ö teadmiste ideoloogia avaldub tähendusloome süsteemina, mille juurde õppijat ärgitatakse. Mitmesuguste lingvistiliste meetoditega on võimalik näidata, missugused tähendused ja vormid õpiku kaudu loomulikustatakse ${ }^{25}$ ja millisena register avaldub. (Vt ideoloogiaanalüüsi Karvonen 1995: 7, 30-33 ja registrianalüüsi kokkuvõtet 197-203.) Teine plaan on õpipsühholoogiline, üld- ja ainedidaktiline ning jääb tekstianalüüsi vaatevälja vaid osaliselt - näiteks õpikomplekt žanrikooslusena ja harjutuste-ülesannete tüübistikuna, mis on õpiteoreetilise mõtte arengu tulemus. Karvonen seda plaani otseselt ei uuri. ${ }^{26}$

${ }^{23}$ P. Karvonen (1995: 161) esitab sõnatähenduste esiletoomise viisid: tekstuaalne esiletoomine samaviitelisuse abil, termini definitsioonide ja selgituste esitamine, terminikujust endast läbipaistev seos liigitelu muude liikmetega.

${ }^{24}$ Ideoloogiast selles tähenduses on juttu allikas Kerge 2008b: 92. Peetakse silmas, et identiteedirühmad mõtestavad sama kõneainet ise viisil ja alusel, toodagu siin näiteks kas või grammatika mõiste süsteemi- ja funktsioonikeskses, ühiskonna- või indiviidikeskses keelekäsitluses, või kitsamalt Eduard Vääri 1968. a eesti keele keskkooliõpiku, Michael A. K. Halliday või Ronald W. Langackeri võtmes jne.

${ }^{25}$ Ingl naturalization on siin kriitilise lingvistika tähenduses kui kontekstinihke (ingl recontextualization; vt Fairclough 2010: 139-141) lõpptulemus. Seda võiks avada eelmise allmärkuse näitel: grammatika tundub algul õpilasele ja varsti ka ühiskonnale iseenesestmõistetavalt ehk loomulikult muutumatu ja ühetaolise keele õigekeelsust toetava süsteemina (nagu Vääri õpiku ajal hariduse omandanutele), kuni lingvistikas levib näiteks arusaamine, et see on leksikogrammatika funktsionaalse terviku rühmiti, paiguti ja ajas varieeruv tahk, kus (väga laias laastus) vorm annab sõnale ja sõnakooslusele funktsiooni ning sõna ja sõnakooslus vormile tähenduse. Kui kooliõpik seletab grammatikat Halliday järgi, nihkub tema mõtteviis teaduskontekstist haridussfäri ning muutub aja jooksul omakorda avalikus sfääris loomulikuks ja õigeks. Nii on see sootsiumis iga mõistega (vt nt Aava 2011 haridusmõistete paradigmamuutuse kohta).

${ }^{26}$ Karvoneni pedagoogilise plaani taustalt tasub esile tuua artiklite kogumikku žanri kohast õppimises (Reid 1987) ja seda, et Karvoneni viidatud uurimuste järgi (nt Ochs 1993; Hakulinen 1993) nähti õppimist ja õpilast tollal veel passiivsena ning esitati teadmisi absoluutse valmistõena, mis osutas õppimiskäsitluse muutumise 
Tekstianalüüsi on Karvonen otsesõnu toetanud John R. Firthi, Michael A. K. Halliday, Ruqaiya Hasani, James R. Martini jt arusaamisele tekstist kui tähendusüksusest, mis on kindlat laadi sündmuse - siinkohal õppimise - üks osa (vt viiteid Karvonen 1995: 221 jj) ${ }^{27}$. Ainekäsitlus haakub viimasele 30 aastale iseloomuliku tekstikontseptsiooniga, mille vältimatu osa on retseptsioon koos selle kaudu tekkiva vastuvõetavuse parameetriga (vt Beaugrande, Dressler 1981/2002). Ideoloogiline analüüs toetub Soome uurimuses samuti autoriteetidele, nt Roger Fowlerile, Gunther Kressile, Robert Hodge'ile ja Norman Fairclough'le. Siinses uurimuses jääb ideoloogiakriitiline tekstianalüüs siiski kõrvale..$^{28}$

Materjali olemuse määratlemiseks on oluline täpsustada uuritavaid žanreid.

Sotsiolingvistilises kirjanduses on žanri mõiste tihti ebamäärane. Paljud ei erista teda registrist üldse, sageli defineeritakse mõlemat ühtviisi. See on viinud järeldusele, et otstarbekas oleks kasutada žanri mõistet siis, kui jutt on registri (valdkonna- ja olusõltliku kõneaine ja väljenduspotentsiaali) keelelisest avaldumisest. Võiks siis öelda, et žanr on registri keeleline avaldis või avaldumise vorm. (Pikemalt Kerge 2000: 87-93, 105-107.)

Tekstide liigitamisel ja uurimisandmete suhestamisel on samas osutunud tähtsaks analüüsida olukohaseid žanreid (ingl situated genre), mitte jääda funktsionaalstiilide kui osa- või allkeelte või üldžanrite (ingl disembedded genre) tasandile (vt liigitelu Fairclough 2010: 67-70). Näiteks on eri liiki era- ja ametikirjade, paber- ja e-kirjade võrdluses selgunud, et olukohaste žanrite parameetrid erinevad oluliselt ja kahes suunas suurte korpusuuringute tulemustest, kus piirdutakse kirjade üldžanriga (vt Kerge 2010a). Vähemalt tuleb teadvustada situatsioone, kuhu materjal kuulub, ja taset, millel üldistused põhinevad.

Ka on argumente, et žanrite uurimiseks ei sobi tasakaalustatud korpus (nt 2000 sõne mahus juhuslikku teksti igast õpikust või 300

vajadusele. Nüüd ongi toimunud selge paradigmamuutus sotsiokognitiivse aluse ja konstruktivistliku praktika poole, kuid see ei ole siinne teema (vt nt Kerge 2011c).

${ }^{27}$ Eesti keeles on samalaadne vaatenurk levinud ja publitseeritud (Kasik 2007; Aava 2011) ning pole põhjust korrata rohkeid viiteid nimetatud autoritele Karvoneni tekstis. Vt vajaduse korral ka Kerge artikleid gümnaasiumi e-valdkonnaraamatus (Kerge 2011a, 2011b, 2011c).

${ }^{28}$ Sel põhjusel ei ole siin esitatud ka kaudseid, s.o Karvonenilt pärinevaid viiteid nimetatud autoritele. 
sõne mahus õpiku igast peatükist), sest andmestik peab sisaldama kõiki uuritava tekstiliigi kompositsioonielemente nendele omase leksikogrammatikaga. $^{29}$

Olukohaste žanrite tunnuseid põhjendatud üldistusastmel uurides uuritakse ühtlasi toimivat keelt selle normaalsetes raamides, mille saavutamine ongi õppekava eesmärk. Sellel alusel määratleme ka oma materjali.

2011. a uurimismaterjal pärineb kahe aine õpikuist: ajalugu 5. ja 6. klassile ning muusikaõpetus 4. ja 7. klassile. Materjali valiku on tinginud projekti alustamise situatsioon märtsis 2011 - õppekava ei olnud veel käivitunud, uus õpivara oli ilmumata, valida sai need värsked õpikud, mida parajasti uue kavaga kohandati. Valiku tegi Avita kirjastus, kes loovutas uurimiseks nii õpikomplektid (vt „Materjali allikad”) kui ka nende sobiva mahuga elektroonilised väljavõtted (tervikpeatükid, kogumaht 13500 sõnet).

Arvutused põhinevad e-andmebaasil, mille maht on tendentside osutamiseks piisav, sest mõni kasutatud meetod on statistiliste korpusuurimuste järgi usaldusväärne 300-400 sõne juures, teine u 2000 juures ning kolmandal juhul on meetod valitud nii, et uuritud teksti maht tulemust vähim mõjutaks. Muusikaõpetuse ja ajaloo e-materjali on võrdselt (üle 6000 sõne kummastki), kuid tekstikogumid on ebaühtlased 4. ja 7. k1 muusikaõpikus (esimene moodustab ligikaudu $30 \%$ ja teine $70 \%$ muusikateksti kogumahust). Põhjus on lihtne: 4 . kl e-andmestikus puudub vähegi pikem informatiivne tekst, kuigi õpikus neid veidi on $^{30}$; peatükkides on lühikesed mõisteselgitused ning rohkesti ülesandeid (vt tagapool). Sel põhjusel ei saa õpikus sidusale tekstile iseloomulikke tunnuseid üldse uurida.

Avita õpikute tekstimaterjali liigitades oleme lähtunud kasutussituatsioonist: õpikutekst õpiolukorras õppimise vahendina. Kaalusime, kas uurida õpikusse kätketud autentset (algselt muul kui õpiotstarbel loodud)

${ }^{29} \mathrm{Nt}$ Douglas Biber tõdeb (1995) nelja keele korpuste võrdluses, et tekstides on suuri erinevusi alustuse, keskosa ja lõpetuse vahel. Huvitavaid üldistusi pakub Mike Nelsoni (2000) doktoritöö veebis avaldatud metodoloogiapeatükk, mis sisaldab Briti korpusuuringute printsiipe: keeleteadus on sotsiaalteadus ja olemuselt rakenduslik; uurima peab ainult terviktekste; võrdlus on tekstide ja tekstitüüpide korpuse uurimisel vältimatu; leksika ja grammatika on lahutamatud jne.

${ }^{30}$ Krifiti Känd on siinse artikli valmimise järel skaneerinud 4. kl muusikaõpikust kogu proosateksti ja analüüsib seda oma bakalaureusetöös (kaitsmine TLÜs 2012). 
teksti koos spetsiaalse õpitekstiga või mitte. Vastus on jah: eakohasel viisil spetsiaalse õpitekstiga tihedalt seotuna pakutakse elulisi tekste, mis on oma esialgse konteksti ja funktsiooni kaotanud. Nende kaasamine tagab ka täpsema ülevaate õpiku keelest. Õpikus kui õpitüüpilises kindlapiiriliste tekstide kogumis oleme eristanud kaht suuremat tekstiliiki:

- ÕPITEKst kui (a) õpiotstarbel loodud teabetekst, s.o sidus proosavormiline laustekst kui õpikutüüpiline žanr, mida tõenäoliselt on võimalik kasutada ka aine iseseisvaks omandamiseks, pluss (b) autentse asjaliku sidusa proosa näidised, mis on õpisituatsiooni tõstetud (rekontekstualiseeritud), et anda õppijale teemakohast lisateavet ja õpetada infot sünteesima ${ }^{31}$ (vt ka kommentaari allpool). Õpiteksti uuritakse igakülgselt;

- MUU ÕPIKUTEKST kui metatekst, mis õpiteksti omandamist toetab ja suunab. Siia kategooriasse on paigutatud (a) temaatilised küsimusja ülesandeplokid kindla õpiteksti kordamiseks ja kinnistamiseks; (b) muu: sidumata tekstid (memod ehk tekstist välja tõstetud ja visuaalselt esiletõusvad olulisima teabe elemendid, peatüki- ja õpikusõnastikud), kuid ka lühikesed õpikuelemente siduvad või neile osutavad vahetekstid ja kommentaarid, illustratsioonide allkirjad. Mõlema alajaotise puhul on uurimiseks loovutatud e-materjali maht žanriti liiga napp, et midagi eraldi analüüsida (nt „Vanaaja” e-failis on ülesandeploki kogumaht 83 sõnet, nn muu teksti maht 233 sõnet jne), kuid visuaalse vaatluse toel on neid õpikutervikus oluline kirjeldada.

2003. a õpiku-uurimuse materjalis on tugevasti esindatud emakeele integreeritud (s.o keeleteadmisi, tekstiõpetust ja kirjandust koos käsitlev) aine, kus kaalukas osa on lihtsatel või keskmise raskusega ${ }^{32}$ autentsetel tekstidel. Seega on sealt võrdluseks olulisemad loodusõpetus ja ajalugu. Laiemaks võrdluseks on kasutatud peamiselt valimit 28 olukohase žanri

${ }^{31}$ Rekontekstualiseerimine kui teksti väljatõstmine tema aktuaalsest diskursusest (dekontekstualiseerimine) ja sisestamine uude konteksti loob võimaluse anda tekstile uus funktsioon (vt nt tavapärasest teksti- ja diskursuseanalüüsist väljaspoolset käsitlust Nevins 2010). Siinse analüüsi materjalis antakse autentsele tekstile (nt ajaleheartiklile, kirjale vms) õpifunktsioon koos peatüki õpitekstiga, nii et olulised aineteadmised sünteesib õppija mitme peatüki kontekstis seostatud allika alusel.

${ }^{32}$ Vt kirjutava ajakirjanduse ning ilukirjanduse tekstide keerukuse kohta Kerge 2002a: 35-36, 42. 
tekstidest ${ }^{33}$ kirjalikke žanreid on valimis 18 (sh 7 monoloogilist ${ }^{34}$; vt Kerge, Pajupuu 2010).

Uuritavaid parameetreid vaagides tuleb arvestada, et teksti keel tähendab koodi asja- ja olukohast valikut (vt Kerge 2000: 89, 105): kindla õpižanri väljenduslaad nõuab õpikukirjutaja keeleharjumuste (nt asjatundjale harjumuspärase erialakeele) kohandamist adressaadi järgi, kuid ka eakohaste autentsete tekstide valikut, millega õ pikut rikastada (vt IRA 1999). Ühe ja sellesama valdkonnaomase teema õpetamisel tähendab see keelevalikute erinevusi olenevalt adressaadi vanusest, kogemusest ja eelteadmistest.

Niisugusel taustal valiti uurimismetoodikaks lingvistiline tekstianalüüs, kitsamalt aga teksti jälgimise ja jooksva mõistmisega seotud keelelised muutujad, mis ainesisu omandamist hõlbustavad või häirivad ning mille jaoks on materjali väikse mahu korral usaldusväärseid mõõdikuid. Kõiki uuritavaid muutujaid ühendab vastuvõetavuse tunnus, mis seostab teksti eesmärki, konteksti ja sihtolukorda (osalejaid, asjaolusid). ${ }^{35}$

Näiteks on pikkade sõnade ja lausetega teksti raske jälgida ning keskmisest tihedamat teksti raske esmalugemise käigus mõista - nii pakkusid huvi teksti raskusaste, nominaalsus (nimisõnamäär) ja leksikaalne tihedus (leksikaalsete sõnade osatähtsus tekstis ja lauses). Sõnavara rikkust sundis arvutama oletus, et keskmisest rikkama sõnavaraga tekstis sõnad ei kordu piisavalt ega jää meelde, väga vaese sõnavaraga tekst aga ei paku huvi ega õpeta sõnakasutust. Teksti väljendustäpsusele viitab ühemõttelisust toetav formaalsus. Iga muutuja kirjeldamiseks valitud meetodit tutvusta-

${ }^{33} \mathrm{Nt}$ raadio otsesaate vestlus ja teleintervjuu, läbirääkimiste ja hoidedialoog; lühikesed parlamendikõned ja suulised lühiettekanded; teismeliste omavahelised erameilid ning töised sise- ja kliendisuhtluse meilid; kirjanike esseistika ja haritud inimeste katselised arvamuskirjutised; Kaplinski avaldatud kirjad ning ametnike omavahelised ja kodanikele saadetud paberkirjad; Eesti ja Euroopa Liidu õigusaktid; SL Õhtulehe uudised eraldi Postimehe omadest, samuti eraldi nende kommentaarid jne.

${ }^{34}$ Interaktiivseks (dialoogiliseks) loeti igat liiki e- ja paberkirjad ning online-kommentaarid.

35 Tekstilisuse standardid kui lingvistilises analüüsis abstraheeritud koostoimelised tahud on Robert-Alain de Beaugrande'il ja Wolfgang Ulrich Dressleril (1981/2002) peatükk-peatükilt avatud - allikas on veebis kättesaadav (lühiülevaade Krista Kerge, Tekstilingvistika ja toimetamine. - Keel ja Kirjandus 2003, 4, 271-280). Vt vastuvõetavuse kohta ka Kasik 2007: 15-19. 
takse tulemuste kontekstis, kuid iga asjakohast mõõdikut ei pruugita kogu materjalil rakendada. Ükski mõõdik ei ole ka absoluutne - näitajaid saab interpreteerida kas uuritud žanreid omavahel või mingite kimpude keskmistega võrreldes või arvestades žanrite muutujaomast järjestust teistes keeltes (näiteks seadused on enamasti kõige formaalsem ja tihedam žanr).

Avita õpikukomplektide kogumahust olenemata on tegu alustava juhtumiuuringuga, mida rikastavad usaldusväärne suuremahuline õpikuuurimus (vt Puksand 2003) ja muude lingvistiliste žanriuurimuste kirjeldav statistika, mis loob teatavate dimensioonide (pidevskaalade) piires žanrite hüpoteetilisi järjestusi. Sedalaadi näitajad ei luba üldistusi väljaspool uuritud materjali.

Tulemuste tõlgendamiseks tuleb kohati kasutada õpikute visuaalset vaatlust, sest tekstide paigutus ja laotus, kirjaliikide valik jm kujundus on samuti teksti vastuvõtu oluline tegur. Õpikomplekti vaatlus annab ka esmaülevaate keelele ja keelekasutusele pööratud tähelepanust.

\section{Õpikuteksti parameetrid, mõõdikud ja analüüsi tulemused}

Jaan Mikk (1979) on juba üle 30 aasta tagasi andnud õppeteksti uurimisele sobiva raami. Kahjuks ei ole selle maailmas väga arvestatava õpiku-uurija metoodikat võimalik mitmel põhjusel kopeerida - see ei ole esiteks programmide tasandil kättesaadav, teiseks aga sisaldab abstraktsete sõnade osatähtsuse küsitavat parameetrit. Viimast on väga raske kalkuleerida, sest see nõuaks kontekstitajuks võimelist analüsaatorit, mis kasutab astmelise abstraktsusmärgendusega sõnastikku. ${ }^{36}$

Allpool avatakse iga uuritud parameetri sisu, tõlgendusvõimalused ja mõõdik, seejärel aga esitatakse muutujate kaupa kõigi uuritud tekstide näitajad. Kindla muutuja arvväärtuste jaotumuse ja hajuvuse mõju püütakse

\footnotetext{
${ }^{36}$ Keel on üldse abstraheerimise vahend; abstraktne ei ole ainult osutus otse vahetu suhtluse kontekstile (kirjalikus tekstis nt isikunimi või teksti siseviide). Isegi kui see unustada, on näiteks demokraatia, armastus ja taevas või analüüsitud õpikute sõnad minarett ja hiidsisalik väga erineval abstraktsusastmel, kuid kõik abstraktsed, kui arvestada keele- ja muu kogemuse lahutamatust ning õpikukasutaja vanust. (Abstraktsusastme arvutus hakkaks muu hulgas sõltuma seotud pildimaterjali tunnustest.) Lisaks tuleb arvestada metafoorsust, mis on keele põhiomadusi. Küll ei sega mõõtmise raskused kogemuslikult väitmast ja näidetega kinnitamast, et ühe sama astme õpiku või peatüki sõnavara on teisest abstraktsem.
} 
kohati tasandada sellega, et võrdlusalustes žanrikogumites on arvutatud aritmeetilise keskmise asemel parameetri mediaan. Viimast võib pidada usaldusväärsemaks, sest keele kui avatud süsteemi puhul on individuaalsed hälbed variandi normist enamasti suhteliselt suured. Arvutused, k.a statistilised, on tehtud Microsofti programmiga Excel. Seosed luuakse järelduste osas.

1. Raskusaste (ingl difficulty) on teksti jälgitavuse (ingl readability) põhimisi parameetreid - mõlemat on tõlgitud ka loetavuseks ${ }^{37}$ (Puksand 2003, 2004). Tunnus osutab struktuuriüksuste hoomatavust lugemise protsessis. Tüvi raske viitab nii eesti õpetajate tavapärasele kõnepruugile kui ka neile sõnalistele hinnangutele, mida allviidatud teadlased jälgitavusindeksite väärtusi seletades kasutavad. Teksti keerukusest (ing1 complicacy) kõneldakse kirjanduses pigem kui mitme mõistmist hõlbustava muutuja kombinatsioonist, kuid sedagi oskussõna kasutatakse paiguti sama mõiste kohta, eriti raskusskaala ühe pooluse nimetamiseks (kerge tekst versus keeruline tekst). Halvasti jälgitavat teksti on ka raskem mõista. ${ }^{38}$

Sandra Harrison ja Paul Bakker (1998) vahendavad jälgitavuse mitmesuguseid definitsioone, mille lähtepunkt on autor, tekst või lugeja. Allpool jäetakse kõrvale autori ja lugeja panusele toetuvad käsitlused ning keskendutakse tekstile. Jälgitavuse tagavad keelelised konstruktsioonid ja sõnavara, mille sobiv kooslus teeb teksti sihipärase kasutamise lihtsaks. William DuBay ülevaate järgi avaldub jälgitavus teksti sõnade ja lausete lugemise lihtsuses. Selle mõõtmiseks on 80 aasta jooksul kasutatud üle 200 valemi, mille usaldusväärsust on uurimustega ka tõestatud. (DuBay 2004: 3)

37 Tõlkevastet loetavus oleks readability vastena hea vältida, sest loetavuseks tõlgitakse tüpograafia- ja kujunduskunsti- ning psühholoogiaterminit legibility - see on loetavus kui esteetika ja taju-uuringute objekt, rõõm teksti silmamisest ja silma töö hõlbustus kirjavalikute, lao tiheduse, teksti paigutuse, sh veeru laiuse jm küljenduse toel, mis ühtlasi küll hoiab ära ka lugemisraskusi. Samas on ka neid autoreid, kes peavad legibility't readability tekstuaalse tahu üheks osaks (vt Harrison, Bakker 1998: 122; vt ka vaatlusandmeid artikli lõpuosas).

${ }^{38}$ Nii inglise kui ka eesti keeles varieerub ka tunnuse „kerge/raske mõista” tähistus kord väljendatakse seda tüve understand / aru saama vormide ja tuletistega, kord tüve comprehend / mõistma toel. 
Siin valisime raskusastme mõõdikuks jälgitavusindeksi Lix, mille rootslane Carl Hugo Björnsson (1968) lõi algselt tekstide võrdlemiseks võõrkeeleõppe kontekstis. Valemit on eesti II kooliastme õpikute hindamisel kasutanud Puksand (2003, 2004). Meetod on lihtne: Lixi arvutamisel summeeritakse lausete keskmine pikkus ja pikkade sõnade osatähtsus ning ümardatakse tulemus täisarvuks (sõna on siin sõne ehk sõnavorm). ${ }^{39}$ Praktiliseks teeb valemi asjaolu, et arvutuse saab teha isegi tekstitöötlusprogrammis (MS Word vm). ${ }^{40}$ Raskusastet mõõdetakse vaid sidusas proosatekstis, jättes kõrvale pealkirjad ja sidumata tekstid (nt tabelid, joonised, memod, nimestikud jm loendid; vt Puksand 2004: 109). Nii on tehtud ka siinses uurimuses.

Björnssoni Lix peaks eesti õpiteksti jälgitavusmõõdikuks sobima. Esiteks eristab lause pikkus eesti tekstiliike juba tõestatult (Kerge 2003; Meier 2003 jm), teiseks vastab valemi pika sõna tähearv pilguga keskmiselt haaratavale (Rayner jt 2001) ning 7 ja enama tähega sõne on ka eesti keeles keskmisest pikem (väljaspool eesti ilukirjandustekste on see üle 6 ja alla 7). Puksand (2004) on Lixi sobivust eesti tekstide mõõtmiseks tõestanud ka eksperimentaalselt. Nimelt lasi ta õpetajatel kogemuslikult määrata nende tekstide raskusastme, mille Lix oli ainult uurijale teada. Näiteks kui eesti koolide õpetajad hindasid teksti uuritava kooliastme õpilasele mõelduna

\footnotetext{
${ }^{39}$ Uurimustes viidatakse mälu ulatusele kui pikimale sõna-, numbri- või täheloendile, mida inimene suudab tajumise järel vahetult meenutada üle pooltel juhtudel - lühimälu haarab korraga kõige rohkem $7 \pm 2$ üksust. On terve rida uurimusi, mis toetavad või kummutavad seda oletamisi juba XIX sajandil püstitatud ja XX sajandi keskel põhjalikumalt analüüsitud nn maagilise seitsme printsiipi. Tundub, et asjakohast arusaama ei ole kummutatud sõna(vormi) kui tähejada pikkuse osas. Küll jäävad selle mäluefekti mõjualast välja sageli korduvad struktuurid. (Vt Wikipedia artiklite „Memory span” ja „Short-term memory” selgitusi ja rohkeid viiteid uurimustele http://en.wikipedia.org/wiki/Memory_span ning http://en.wikipedia.org/wiki/Shortterm_memory; 12.01.2012.) Kuna keel on avatud süsteem, siis kordub õpikulause kui samade sõnade ja sõnavormide kindlas järjestuses kombinatsioon seda väiksema tõenäosusega, mida pikem ta on. Nii peaks Lixi kasutamine olema ka praeguste taju-uurimuste kontekstis õigustatud. Küll järeldub siit, et Lixi ja muude muutujate kõrval oleks vaja uurida siin kõrvale jäetud lauseliigendust ja nn leksikaalseid kimpe (sõnade tekstiliigiti korduvaid kollokatsioone); viimaseid peetakse üldiselt tugevaks registrieristajaks (vt nt Levy 2008).

${ }^{40}$ Argikasutust võib takistada asjaolu, et Lix on tõenäoliselt ebatäpne, kui teksti maht jääb alla 200 lause ja alla 2000 sõne (Jacobsen Khan 2010: 4).
} 
kergeks, siis oli selle Lix vahemikus 25-37, kui raskeks, siis üle 45, muud seal vahel. Tulemused sarnanevad sellega, mida sama mõõdiku järgi on peetud kergeks või raskeks tekstiks (vt tabel 1).

Björnssoni valemit on muude seas kasutatud Suurbritannias ${ }^{41}$ (nt Harrison 1980) jm. Hiljaaegu on Björnssoni (1969) Lixi toel võrreldud taani- ja ingliskeelseid kohtuotsuseid seisuga enne ja pärast keelereforme, mis toimusid Taanis 1999 ja Suurbritannias 2003 (Jacobsen Khan 2010). Seal on Lixi sõnalised hinnangud seotud arvväärtuste täpsustatud skaalaga; vt tabel $1 .{ }^{42}$

Tabel 1. Arvväärtuste sõnalised hinnangud Lixi skaalal ning eesti õpetajate sõnaliselt hinnatud tekstide Lix Puksandi (2003, 2004) järgi

\begin{tabular}{|c|c|c|c|c|}
\hline $\begin{array}{l}\text { Björnssoni } \\
\text { (1968) } \\
\text { Lix }\end{array}$ & $\begin{array}{l}\text { Taani-inglise } \\
\text { tekstide } \\
\text { täpsustatud arv- } \\
\text { väärtustega Lix }\end{array}$ & $\begin{array}{l}\text { Sõnaline } \\
\text { hinnang } \\
\text { (ka eesti } \\
\text { õpetajate } \\
\text { katses) }\end{array}$ & \multicolumn{2}{|c|}{$\begin{array}{l}\text { Eesti õpetajate sõnaliselt } \\
\text { hinnatud tekstide Lix }\end{array}$} \\
\hline $20-25$ & kuni 24 & väga kerge & & $\begin{array}{l}\text { (hinnangut pole kasu- } \\
\text { tatud, kuid ala kattub } \\
\text { taani-inglise tekstide } \\
\text { võrdlusega) }\end{array}$ \\
\hline $30-35$ & $25-34$ & kerge & $25-37$ & $\begin{array}{l}\text { (hinnangud kattuvad } \\
\text { üldjoontes taani-inglise }\end{array}$ \\
\hline $40-45$ & $35-44$ & keskmine & $36-44$ & $\begin{array}{l}\text { tekstide võrdlusega, } \\
\text { piiriala kerge ja } \\
\text { keskmise vahel veidi } \\
\text { ebamäärane) }\end{array}$ \\
\hline $50-55$ & $45-54$ & raske & $\begin{array}{l}45 \text { või } \\
\text { enam }\end{array}$ & $\begin{array}{l}\text { (hinnang kattub } \\
\text { taani-inglise tekstide } \\
\text { võrdlusega) }\end{array}$ \\
\hline 60 ja enam & 55 ja enam & väga raske & & $\begin{array}{l}\text { (hinnangut pole kasu- } \\
\text { tatud) }\end{array}$ \\
\hline
\end{tabular}

${ }^{41}$ Palju on kasutusel valemeid, mis arvestavad ka silpide arvu, kuid rohket kirjandust lugedes tundub, et enam on neid kasutatud suulise teksti jälgitavuse mõõtmisel ja eriti inglise vm sellise keele puhul, kus hääldus kirjapildist tugevamini erineb.

42 Jacobsen Khan 2010: 19-21 viitab allikale Henrik Galberg Jacobsen, Peder SkyumNielsen, Dansk sprog. En grundbog. Schønberg, 1996, 30-31. 
Björnssoni originaalskaala rõhutab oma nimetamata vahemikega teadlikult astmepiiride suhtelisust; nii on Jacobsen Khani liigendus skaala üks võimalikke tõlgendusi. See tõlgendus näib aga vägagi sobivat eesti õpetajate hinnangutega II kooliastme tekstidele (ainult tekst Lixiga 35-37 näitab selle skaala astmepiiride imeväikest hägusust). Jacobsen Khani skaala alusel võiks õpiteksti raskusastet allpool ka hinnata.

Lixi ja selle tegurite arvväärtused leiab tabelist 2. Kahe (täiskasvanute) keelekasutusvaldkonna tekstide raskusaste on arvutatud selle uurimuse jaoks põhjendusega, et kirjutav ajakirjandus on varem osutunud keerukuselt keskmiseks (vt Kerge 2002a: tabel 5) ja õpitekstid põhinevad teadusel. ${ }^{43}$

Jaan Miku (1991) järgi on 6. klassile sobiv lause pikkus u 12 sõna ning täpselt selline on värskelt uuritud Avita õpikute keskmine. Miku soovitus haakub viie eesti keele kasutusvaldkonna keskmiste näitajatega: lause keskmine pikkus on sajandivahetusel olnud 11,4 sõnet, kui õigusaktid kõrvale jätta, ja u 14, kui need kaasata (Kerge 2002a). Tabelist 2 nähtub, et see Lixi tegur on 2003. aastast väljaspool emakeeleainet 1,5 sõne võrra kasvanud ja et kõigi õpikute laused on eakohaselt lühemad kui täiskasvanutele mõeldud tekstis. Eriti selgesti on õpikulause lühem tabloidide ja siinse valimi teadusteksti omast. ${ }^{44}$

Emakeeles on suur kaal lihtsatel ilukirjandus-, meedia-, rahvaluulejms tekstidel, kus Lixi keskmise viib alla hoopis pikkade sõnade 13-14\% väiksem määr (vt Puksand 2004: 117 jm). Ka ei erine õpiteksti üldine raskusaste võrdlustekstidest nii tugevasti, kui lühike lause oletada lubaks. Seepärast võeti eritähelepanu alla pikad sõnad. ${ }^{45}$

${ }^{43}$ Lixi pole enne Puksandit Eestis keegi kasutanud ja pikkade sõnade osatähtsust on arvutatud teistel alustel (vt Maanso 1982; Meier 2003). Katselised võrdlusandmed leiti Tartu Ülikooli kirjakeele korpusest mõlema allkeele jaoks kahe 1000 lause päringuga: a) nn tabloidid on Eesti Ekspress 1997-2001 ja SL Õhtuleht 2007 ning nn soliidsed lehed Maaleht 2001-2004, Postimees 2000 ja Eesti Päevaleht 2007; b) teadusest valiti varasema aja alamkorpus tehnilistel põhjustel (uues korpuses on täpitähed SGML-kujul, mis seganuks sõnapikkuse arvestamist) - kuid võib ka oletada, et just varasemad teadustulemused on jõudnud õpikutesse.

${ }^{44}$ Kerge (2002a) nelja humanitaar- ja sotsiaaleriala teadustekstide valimi lausetes oli õpikutega märksa sarnasemalt 12,6 sõnet lause kohta ehk 7 sõna vähem, kui siin leiti. Korpuste tekstivalikus on seega küsitavusi.

${ }^{45}$ Napis valimis tervikuna (vt tabel 2) näitab küll determinatsioonikordaja, et Lixi mõjutab tugevasti just lause pikkus; pikkade sõnade mõju jääb sellele umbes kaks korda alla. 
Tabel 2. Eesti õpiteksti raskusastme näitajad aastatel 2011 ja 2003 võrdluses muud liiki tekstidega*

\begin{tabular}{|l|c|c|c|c|}
\hline \multicolumn{1}{|c|}{ Materjal } & $\begin{array}{c}\text { Lause } \\
\text { pikkus }\end{array}$ & $\begin{array}{c}\text { Sõna } \\
\text { pikkus }\end{array}$ & $\begin{array}{c}7+\text { tähte } \\
\text { sõnas \% }\end{array}$ & Lix $^{46}$ \\
\hline Ajalugu, 5. kl, 2011 & 11,8 & 6,7 & 48,5 & 60 \\
\hline Ajalugu, 5. kl, 2003 (Koolibri) & 13,7 & 6,4 & 44,9 & 58 \\
\hline Ajalugu, 5. kl, 2003 (Avita) & 10,8 & 6,4 & 42,9 & 54 \\
\hline Ajalugu, 6. kl, 2011 & 11,6 & 6,6 & 44,3 & 56 \\
\hline Loodusõpetus, 4. kl, 2003 & 8,9 & 5,9 & 38,9 & 48 \\
\hline Loodusõpetus, 5. kl, 2003 & 9,3 & 6 & 40,1 & 49 \\
\hline Loodusõpetus, 6. kl, 2003 & 9,7 & 6,4 & 45,1 & 55 \\
\hline Emakeel, 2003 (2 kirjastust) & 10,8 & 5,5 & 29,8 & 41 \\
\hline Muusika, 7. kl, 2011 & 12,7 & 6,8 & 49,7 & 62 \\
\hline $\begin{array}{l}\text { Õpikud (v.a emakeel), 2003 } \\
\text { (2 kirjastust) }\end{array}$ & 10,5 & 6,2 & 42,4 & 53 \\
\hline $\begin{array}{l}\text { Õpikud (k.a emakeel), 2003 } \\
\text { (2 kirjastust) }\end{array}$ & 10,7 & 5,9 & 35,6 & 46 \\
\hline Õpikud, 2011 (Avita) & 12 & 6,7 & 48 & 60 \\
\hline $\begin{array}{l}\text { Õpikud (v.a emakeel), } \\
\text { 2003-2011 }\end{array}$ & $\mathbf{1 1 , 1}$ & 6,4 & $\mathbf{4 4 , 3}$ & $\mathbf{5 5}$ \\
\hline Päevalehed 2011, sh & 16 & 6,3 & 40,4 & 56 \\
\hline \multicolumn{1}{|c|}{ soliidsed lehed } & 14,7 & 6 & 36 & 51 \\
\hline tabloidid & 17,6 & 6,6 & 44,7 & 62 \\
\hline Teadus, 1980ndad & 19,4 & 6,4 & 42,8 & 62 \\
\hline
\end{tabular}

* Hallil taustal on 2011. a andmed. Lause pikkus on kõikjal sõnedes, sõna pikkus on lingvistilises mõttes sõne tähemärkide arv; 7+ tähte on 7- ja enamatäheliste sõnede osatähtsus.

Torkab silma, et nt kolmes uuritud 5. klassi ajalooõpikus, mis oskussõnavaralt võiksid sarnaneda, erineb 7- ja enamatäheliste sõnade määr 5-6\%. Sama klassi sama aine õpikute vahel on suuri erinevusi leidnud ka Puksand (2003). Lisaks on teadlased pikka sõna resp. sõnet erinevalt mõtestanud. Uurisime ülipikki sõnu võrdluseks ka raskusastmearvutuste värskes tekstivalimis.

Heidi Meier (2003: tabel 6) on leidnud 14 ja enama tähega sõnesid nt esseistikast $1 \%$, ilukirjandusest $0,5 \%$, ajakirjandusest $1,3 \%$ ja teadus-

${ }^{46}$ Lixi standardhälve on kogu õpikuvalimi kohta 6,61, kuid emakeeleõpikuid arvestamata 4,92 . 
tekstidest 1,8\%. A. Annuse (2011) järgi on neid 6. kl „Vanaajas” märksa enam, sh vältimatult korduvate terminite nüüdisinimene, neandertallane, koopamaaling mitmesugused käändevormid. Siinses võrdlusvalimis erinevad trükimeedia ja teaduse andmed Meieri omadest oluliselt ning näitaja kasvab sihtrühma vanuse ja kogemusega kooskõlas (vt veergu „14+ tähte" tabelis 3). Kui oleksime toetunud Meieri teadustekstiandmetele, siis oleks ülipikki sõnu teadusega ligi võrdsel määral juba 4. klassis, kus lugemistehnika on veel suhteliselt nõrk.

V. Maanso (1982) on õpikutes mõõtnud 12- ja enamatäheliste sõnede osatähtsust: väljaspool emakeeleõpikuid on see $10 \%$. Tabeli 3 veerus ,12+ tähte" ei vasta näitajate järjestus erinevalt eelkirjeldatust (,14+ tähte”) praegu sellele, mida eakohaselt võiks eeldada. Nagu näha, on 12 ja enama tähega sõnede määr kõikjal väiksem kui Maanso õpiku-uurimuses 20 aastat tagasi. 7. klassi muusikaõpiku väga raske (suurima Lixiga) tekst ei erine siin suurt ei kirjutava meedia tekstist ega kuigivõrd teadustekstistki. ${ }^{47}$

Tabel 3. Ülipikkade sõnade osatähtsus 2011. aasta tekstivalimis

\begin{tabular}{|c|c|c|c|c|}
\hline \multirow{2}{*}{ Adressaat } & \multirow[b]{2}{*}{ Allikas } & \multicolumn{3}{|c|}{ Ülipikki sõnu $\%{ }^{48}$} \\
\hline & & 14+ tähte & & $12+$ tähte \\
\hline \multirow{4}{*}{$\begin{array}{l}\text { Põhikool: } \\
\text { II aste }\end{array}$} & muusika, 4. kl & 1,9 & 5,6 & $\begin{array}{l}\text { (1,6\% alla valimi } \\
\text { keskmise) }\end{array}$ \\
\hline & ajalugu, $5 . \mathrm{kl}$ & 2,6 & 7,3 & $\begin{array}{l}\text { (valimi keskmise } \\
7,2 \% \text { lähedal) }\end{array}$ \\
\hline & ajalugu, 6. kl & 3,1 & 4,7 & $\begin{array}{l}(2,5 \% \text { alla valimi } \\
\text { keskmise) }\end{array}$ \\
\hline & muusika, $7 . \mathrm{kl}$ & 3,3 & 8,2 & $(1-1,3 \%$ üle \\
\hline Täiskasvanud & trükimeedia & 4,3 & 8,5 & keskmise) \\
\hline Asjatundjad & teadus & 4,5 & 9 & (1,8\% üle keskmise) \\
\hline
\end{tabular}

Mitte-emakeeleõpikute raskusaste näib esmapilgul võrreldes 2003. aastaga oluliselt kõrgem. Siiski, värske materjal sisaldab rasket III kooliastme muusikaõpikut. II kooliastme tekstide keskmine raskus erineb ajateljel ebaoluliselt (Lix kasvas 53-lt 54-le). Kvalitatiivset tähelepanu vajavad

47 7. kl muusikaõpiku ja teadustekstide erinevus ületab 12 ja enama tähega sõnade osas veidi valimi standardhälvet $(0,791)$.

${ }^{48}$ Hajuvus on Heidi Meieri (2003) andmeid aluseks võttes sõnarühmiti erinev: 14 ja enama tähega sõnede puhul on standardhälve 0,$792 ; 12+$ tähe rühmas 1,717 . Siinse tabeli järgi on see erinevus veidi väiksem (hälve 0,993 ja 1,172). 
siiski nii 7. kl muusikaõpik kui ka 5. kl inimajalooõpik, mille õpitekst on väga raske. Ühest küljest on vaja uurida enam-vähem ühepikkuste lausetega teksti teise raskusteguri, s.o pikkade ja ülipikkade sõnavormide osatähtsuse põhjusi. Teisest küljest, millised tahes need põhjused oleks, tehnilises mõttes on pikka sõna raske lugeda ka siis, kui tema sisu raskusi ei tekita (nt reeglipäraste liitsõnade või tuletiste mõistmine).

Raskusastmete tõlgendamisel tuleks siiski arvestada mitut asjaolu. Esiteks lugeja iga: didaktikakirjanduse järgi ületatakse lugemise tehnilised raskused enamasti just esimese kuue klassiga (vt Kerge 2010b), st 7. klassis võikski teksti raskusaste julgemini kasvada. Teiseks eesti grammatika: keele vormi- ega sõnamoodustus ei muutu kuigivõrd kiiresti (st pikki sõnavorme, liitsõnu ja tuletisi ei tohiks ajaga oluliselt lisanduda), järelikult tuleb otsida sõnade pikkuse põhjusi muutunud ainespetsiifikas (terminite võõrtüved, nimed vm) - küsimus on, mil määral neid on võimalik vältida. Kolmandaks on raskusastme tõlgendamisel oluline, et sõnade korduvus lubab pikki tähejadasid hõlpsasti haarata (seda teemat vt osast „Õpikute sõnavara"). Samal põhjusel oleks tähtis uurida korduvate kollokatsioonide (lekseemikimpude) laadi ja määra. Taustal vajab uurimist seegi, miks on lause pikkus ja ülipikkade sõnede määr teadustekstis allikati nii erinev.

2. FormaAlSUSASTE näitab teksti ühemõttelisust, mis on ennekõike väljendustäpsuse näitaja. Selle muutuja arvutamise metoodika ja mõõdiku F-indeks on välja töötanud Francis Heylighen ja Jean-Marc Dewaele (2002). Võib oletada, et nii liigne ühemõttelisuse taotlus kui ka liigne toetumine kontekstile kahandab ka jälgitavust: tekst on kas ebaloomulikult formaalne või lihtsustatud.

Lingvistilise formaalsuse-kontekstuaalsuse dimensiooni ideoloogia (Heylighen, Dewaele 2002) lähtub sellest, et nimisõnad kui viitejõulised kasvatavad koos omadus- ja kaassõnadega teksti ühemõttelisust (formaalsuse poolus) ja muud sõnaliigid mitmemõttelisust (kontekstuaalsuse poolus). Näiteks toetub kontekstile 7. kl muusikaõpiku 17-sõnaline ehk keskmisest pikem lause, kus on ainult 4 nimisõna (alla joonitud) ning ühtaegu ridamisi asendussõnu ehk provorme (kapiteelkirjas), mis viitavad lähikontekstile või jätavad lause umbmääraseks.

(1) IgALE raagale [eespool seletatud termin] vastab KINDEL meeleolu ning SAGELI ka aeg ning koht, MILLAL ja KUS SEDA [asendussõnad viitavad avara tähendusega nimisonnadele lause enda kontekstis] esitada sobib. 
Mingist muust allikast (teadmiskontekstist) tuleks otsida teemaks võetud raagade liike, nende meeleolu laadi ja esitustavade piiranguid. Kui vahetult järgnev tekst sisu ka avaks (seda ta ei tee), jääks näide (1) ise suhteliselt kontekstuaalseks - järgnevgi on juba selle lause lähikontekst.

Formaalsuse-kontekstuaalsuse olemuse selgitused, mõõtmise teoreetilised argumendid, eesti sõnaliikide määramise erisused jms võib leida Kerge jt (2007) ${ }^{49}$ vahendusel; sealt leiab ka formaalsusindeksi F eesti keelele kohandatud valemi. Kerge ja Pajupuu (2010) on arvutanud 28 žanri F-indeksi ning analüüsinud ka kommunikatiivsete tegurite mõju sellele. Tulemused on võrdlevalt esitatud tabelis 4. Ei selle tabeli ega järgmistegi võrdlusandmed ei arvesta õpikunäitajaid (st nii kirjalikud žanrid kui ka kirjalik monoloog on arvutatud õpikutest eraldi). Piirväärtuste tõlgenduses tuleks arvestada, et meetodi autorite järgi on statistiliselt oluline juba kolmepunktiline erinevus.

Seni uuritud žanrite järgi võib oletada, et optimaalne õpikusse sobiv formaalsusaste võiks olla kirjaliku teksti või kirjaliku monoloogilise teksti mediaan - need on ka peaaegu ühesugused (u 50).

Tabel 4. 2011. a uuritud õpiteksti formaalsusaste (vt võrdlusallikaid ülal)

\begin{tabular}{|l|l|}
\hline Allikas & F-indeks (oluline erinevus juba 3 punkti) \\
\hline Ajalugu, 5. kl & 62 \\
\hline Ajalugu, 6. kl & 55,2 \\
\hline Muusika, 7. kl & 57,8 \\
\hline Teismeliste omavahelised meilid & 32,4 \\
\hline Eesti tekst (suuline ja kirjalik), sh & $\begin{array}{l}\text { mediaan } 43,2 \\
\text { piirväärtused 28,6-75 }\end{array}$ \\
\hline suulised žanrid & $\begin{array}{l}\text { mediaan } 34,8 \\
\text { piirväärtused } 28,6-47\end{array}$ \\
\hline kirjalikud žanrid & $\begin{array}{l}\text { mediaan } \mathbf{4 9 , 6} \\
\text { piirväärtused } 32,4-75\end{array}$ \\
\hline $\begin{array}{l}\text { kirjalik monoloog õigusakte } \\
\text { arvestamata }\end{array}$ & $\begin{array}{l}\text { mediaan } \mathbf{4 9 , 5} \\
\text { piirväärtused 35,5-52,8 }\end{array}$ \\
\hline
\end{tabular}

${ }^{49}$ Tekst on CEEOLi (Central and Eastern European Online Library, www.ceeol.com) kaudu veebiotsinguga kättesaadav ja olemas ETISes (Eesti Teadusinfosüsteem, www.etis.ee) selle artikli autorite publikatsioonide hulgas. 
Kui võrrelda näitajaid teismeliste omavahelises meilivahetuses ilmnevate keeleharjumustega (hall taust), võib järeldada, et asjalikel koolitekstidel on oluline osa sellise väljendustäpsusega harjutamisel, mida läheb hiljem vaja asjalikus ja täppissuhtluses.

Võrreldes 50 piirile jääva n-ö ideaalnäitajaga on õpikud liiga formaalsed. Kui isegi kolmepunktiline erinevus on oluline, siis väärib tähelepanu, et 5. kl ajalooõpik on 7 punkti suurema F-indeksiga kui järgmise klassi oma. Tugeva ühemõttelisustaotluse eest, mida õpiteksti suur formaalsusaste näitab, makstakse lõivu arusaadavuse pealt (vt järgmist parameetrit $\left.{ }^{50}\right)$.

3. NominaAlsus on üks teksti arusaadavuse ${ }^{51}$ kriteeriume. Seda vaadeldakse nimisõna- versus tegusõnavormide osatähtsusena tekstis. Tunnus avaldub kui noomeni- ja verbikasutuse optimaalne suhe: keskmisest nominaalsemat teksti on raskem mõista. Parameeter näitab teksti temaatilist tihedust - nimisõnad on ainus viitejõuline sõnaliik, kõik muud sõnad mõtestatakse nende najal ${ }^{52}$; nii teeb suurem nominaalsus referentsiahela ehk viidatavate mõistete ahela tihedamaks ja teksti mõtestamise raskemaks. (Vt Kerge 2010a.) Võib oletada, et tugevasti nominaalset teksti tuleb mõistmiseks korduvalt üle lugeda.

Teksti suhtelise temaatilise tiheduse markerina lubab nimisõnasagedust ehk nominaalsust näha asjaolu, et nimisõnad kannavad teemat (the ideational content is densely packed in nominal construction, vt Halliday 1994: 352). Mida spetsiifilisem või täpsem (ingl the more specialized) on

${ }^{50}$ Determinatsioonikordaja järgi oleneb F (ja väljendustäpsus) žanrite võrdlusandmestikus u 97\% ulatuses nimisõnavormide osatähtsusest, väga väike mõju (2-3\%) on adjektiividel. Verbide hulk mõjutab F-indeksit vastupidises suunas keskmisel määral; tugev negatiivne mõju on adverbidel (vt statistikamõisteid Niglas 1997).

${ }^{51}$ Arusaadavuse sõna oleme definitsioonides eelistanud põhjusel, et teksti mõistmine viitab lugemisoskuse kirjanduses ka esmaselt arusaadava sisu ja eelteadmiste (teadlikule) sünteesile, selle rakendusoskusele jms (vt Pricilla E. Griffithi ja Jiening Ruani jt artikleid kogumikus „Metacognition in Literacy Learning”, Israel jt 2005).

${ }^{52}$ Piltlikult - olend, asi või nähtus kannab omadusi ja just talle omistatakse olekuid, seisundeid, tegusid, tegevusi või asetatakse ta juhtumite ja protsesside kulgu. Nii on näiteks verbe keeliti suhteliselt vähe, nad on sageli avara- ja mitmetähenduslikud ning neid modifitseeritakse abisõnade ja liidetega. Nominaalne stiil muudab seega tihedaks koherentse teksti ehk mõtte- ja mõisteseosed jooksva teksti taga. Leksikaalne tihedus näitab seevastu pigem kohesiivse ehk pindmise teksti kulgu. 
tekst, seda rohkem nominaalfraase ja vähem verbe kaldub temas olema. Näiteks on Basey E. Antia (2000: 159) mitme keele keskmisena saanud nimisõnavormide osatähtsuseks oskustekstis $40 \%$ ja üldkeeles $28 \%$.

Võrdlusandmed on allpool (vt tabel 6) samadest täiskasvanužanritest mis F-indeksite puhul (Kerge, Pajupuu 2010). Lisatud on Kaplinski proosakeele (Põld 2008) ja teismeliste erameilide (Kerge 2010a) andmed; need iseloomustavad täiskasvanute ja noorte enda igapäevast keelekasutust. Esile tuuakse ka nimi- ja tegusõnade omavaheline suhe (protsendina nende summast) - see võiks olla kõnekam kui mitme keele põhjal siin-seal tehtud oletus, et verbivormide optimaalne ehk mõistmist soosiv osatähtsus tekstis on 19-24 ja oleneb keelest.

Tabel 5. Nominaalsus ja verbilisus 2011. a õpitekstis (\% sõnedest). Võrdlusandmete alus Kerge, Pajupuu 2010

\begin{tabular}{|c|c|c|c|}
\hline $\begin{array}{l}\text { Sõned } \rightarrow \\
\text { Allikas } \downarrow\end{array}$ & Nimisõnu & Tegusõnu & $\begin{array}{l}\text { Nimi- ja tegu- } \\
\text { sõnade suhe }\end{array}$ \\
\hline Ajalugu, 5. kl & 45,4 & 18,2 & $70: 30$ \\
\hline Ajalugu, 6. kl & 37,8 & 19,7 & $65: 35$ \\
\hline Muusika, 7. kl & 41,9 & 19,2 & $69: 31$ \\
\hline Õpikud 2011 & 41,7 & 19 & $68: 32$ \\
\hline $\begin{array}{l}\text { Teismeliste oma- } \\
\text { vahelised meilid }\end{array}$ & 20,6 & 22,1 & $48: 52$ \\
\hline Kaplinski romaan & 22 & 22 & $50: 50$ \\
\hline $\begin{array}{l}\text { Eesti tekst (suuline } \\
\text { ja kirjalik), sh }\end{array}$ & $\begin{array}{l}\text { mediaan } 32,1 \\
\text { piirväärtused } \\
17-62,5\end{array}$ & $\begin{array}{l}\text { mediaan } 21,05 \\
\text { piirväärtused } \\
26,3-10,7\end{array}$ & $60: 40$ \\
\hline kirjalikud žanrid & $\begin{array}{l}\text { mediaan } 35,8 \\
\text { piirväärtused } \\
20,6-62,5 \\
\end{array}$ & $\begin{array}{l}\text { mediaan } 19,1 \\
\text { piirväärtused } \\
24-10,7\end{array}$ & $65: 35$ \\
\hline $\begin{array}{l}\text { kirjalik monoloog } \\
\text { üldse või õigus- } \\
\text { aktideta }\end{array}$ & $\begin{array}{l}\text { mediaan } \\
37 / 34,5 \\
\text { piirväärtused } \\
22-54,7 / 42,9\end{array}$ & $\begin{array}{l}\text { mediaan } \\
20,3 / 21,7 \\
\text { piirväärtused } \\
12,3 / 19-24\end{array}$ & $65: 35$ \\
\hline
\end{tabular}

${ }^{53}$ Nominaalsus ja verbilisus on tugevas negatiivses korrelatsioonis, kuid pigem keskmise piiril $(\mathrm{r}=-0,724)$. Vt korrelatsioonikordaja täpsustatud tugevusskaala selgitusi Niglas 1997: 55. 
Õpitekstinäitajate hindamisel võiks vaadata kirjaliku monoloogi iseloomustust, mis viitab probleemidele 5. klassi ajalooõpikuga. Kui nimetatud monoloogkirjutiste hulgast välistada äärmuslikud Eesti ja Euroopa Liidu õigusaktid ${ }^{54}$, siis on siin tegusõnu žanriti pea ühepalju $(21,5 \pm 2 \%$ verbivorme), kuid nimisõnamäär on võrdlusmaterjalis väga žanritundlik ${ }^{55}$ (vt piirväärtusi).

Õpikus tuleb terminid arusaadavalt lahti seletada ja sujuvalt taksonoomiatesse siduda (Karvonen 1995). Võib siis oletada, et õpitekstis on nimisõnu pisut enam, kui on tavapärane eesti keeles üldiselt või kitsamalt kirjalikes tekstides (st veidi üle 32-35\%).

Niisugusel taustal võib alla 38\% nimisõnadega 6 . kl ajalooõpikus enam-vähem rahule jääda, kuid 7. kl muusikaõpiku 42\% vajab tähelepanu ning 5. kl ajaloo $45-46 \%$ peaks olema liig. Piirata saab nimisõnamäära, kui eelistada lauselisi selgitusi loenditele või kommentaaridele lause osana.

Kommenteerime siinkohal paari näidet (samad näited aitavad tagapool illustreerida järeldusi parameetrite seoste kohta).

Kõigepealt mõned 6. kl ajalooõpiku näited.

- Omatermin on samastavalt rinnastatud võõrterminiga, mis üldkeelesõnana on tõenäoliselt õppijale juba tuttav (filmi- ja raamatutegelased, mänguasjad vm) ja mida omakorda toetab sulgudes kommentaar.

(2) Umbes 230-65 mln aastat tagasi asustasid Maad HIIDSISALIKUD EHK DINOSAURUSED (see sõna tähendab kreeka keeles kohutavat sisalikku).

- Läbipaistvale omaterminile lisatakse võõrtermin sulgudes.

(3) Paljud teadlased arvavad, et dinosauruste väljasuremise põhjustas Maad tabanud TAEVAKEHA (ASTEROID) ja sellele järgnenud tohutu plahvatus.

${ }^{54}$ Formaalsed institutsionaalsed žanrid mõjuvad nominaalsuse-verbilisuse keskmisele pildile tugevasti (õigusaktides on verbimäär 12-13\% ja ametnike kirjades 10-14\%).

${ }^{55}$ Nimisõnasageduse hajuvus skaalal on väga suur (standardhälve 12,70). Verbimäära hajuvus on väiksem (standardhälve 3,86). Verbide puhul on kogu võrdlusvalimi (eesti keele) kvartiilide vahe 3,33, nimisõnade puhul on see 16,15 (vt mõisteid Niglas 1997). 
- Ülemmõiste (A) on esitatud alammõiste (a) eeslisandi A vormis ja samas fraasis on veel täpsustavaid või piiritlevaid täiendeid.

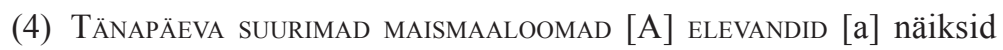
nende kõrval lausa kääbustena.

- Tekstilausesse poetatud ülemmõistet avavad sulgudes loetletud alammõisted.

(5) Paljude loomaliikide seas arenesid aja jooksul ka imetajad ja nende hulgas esimesed väikesed ahvisarnased loomad. Neid peetakse nii tänapäeva INIMAHVIDE (GORILLADE, ŠIMPANSIDE JA ORANGUTANIDE) kui ka inimeste ühisteks eellasteks.

Määratlust lausena esitada on palju võimalusi: a on $x$; $x$-i iseloomustavad / $x$-le on iseloomulik(ud) y ja $z$; $x$-i nimetatakse a-ks; a tähendab $x$-i; nii $a$, $b$ kui ka c on $x$ - $d$; $x$-d on näiteks a ja $b$ jne. Lause peaks olema kõige lihtsam määratlemise tee, kuid asi ei ole nii ühene. Siinkohal paar näidet 7. klassi muusikaõpikust.

- Näitelause (6) öeldise järel antakse juudi definitsioon nimisõnafraasi kujul.

(6) Sõna ,juut" tähendab eelkõige JUUDI USUNDI JUDAISMI tunnistajat.

Täiendisse juudi usu judaismi on kätketud ebamäärased mõistesuhted: ei ole selge, kas judaism on üks juudiusundeid või samastatakse need kaks (mille puhul oleks parem lisada samastav sidend ehk). Kogu määratlus eeldab ka ühendi usku tunnistama või liitsõna usutunnistaja tundmist või õpetajapoolset seletust; muidu on võimalik ka tõlgendus 'tunnistaja roll judaismi piires' (mida tahes tunnistama ja tunnistaja õpilasele tähendaks).

- Kohati ei ava lauseline selgitus oma abstraktsuses midagi - näide (7) eeldab lugejalt kõigi loetletud terminite tundmist või autori teadlikku eeldust, et sõnad jäävad meelde ja õpilane leiab ise neile (kohe või hiljem) tähenduse.

(7) Hiina mütoloogia on segu ŠAMANISMIST, BUDISMIST, TAOISMIST ja KONFUTSIANISMIST.

Liide -ism maailmavaate, veendumuste, tunnetusviisi ligilähedases tähenduses ja -ist nende kandja omas peaks 7. kl keelekogemusse 
juba kuuluma (sotsialism, satanism vm). Määratluse mõte on siis õpilase jaoks tõenäoliselt 'segu mitmest [ISM]ist' vms. (Tegemist ei ole ju muusikaterminitega.)

- Ükski vorm ei aita selgitusi mõista, kui võõrast aineterminit (vokaal) iseloomustada omakorda terminite kaudu, mis võivad olla tuttavad või ei (õpiku sõnastikus pole vokaali, ühehäälsust ega nasaalsust; tõsi, ühehäälsus kordub lähikontekstis 4 korda, kuid nasaalsus mitte).

(8) Pekingi ooperis kasutatakse laulu, pillimängu, deklamatsiooni, tantsu ja akrobaatikat. Vokaal on valdavalt ÜHEHÄÄLNE, lauldakse kõrge NASAALSE HÄÄLEGA.

Seda rida võib jätkata, kuid selgeks saab kaks asja. Esiteks juhivad näited tähelepanu õpiteksti kvalitatiivse sõnavara- ja sõnastusanalüüsi tähtsusele. Teisalt saab selgeks, et suurem nominaalsus kui teaduse ja teaduspõhiste tekstide üsna tüüpiline joon vajab kvalitatiivset uurimist kogu eesti žanriruumi ulatuses. Ehkki suuremat nominaalsust ongi spetsiifilisemates tekstides eeldatud, näivad lingvistid (nt Kerge 2003 või Kasik hiljutises ettekandes ${ }^{56}$ ) tegelevat enam nominalisatsiooni kui nimisõnade üldise rohkuse põhjustega sellistes tekstides. Kumbki eeltoodud asjaolu ei muuda aga tõsiasja, et õpitekst on temaatiliselt tihe, kohati liigagi tihe ning segab aine omandamist, kui mõisteid omakorda seletada tundmatute terminite, harvade võõrsõnade, ebamäärase tähendusega tarindite jms toel või tekstilause sügavamates kihtides (vt ka osa 5 „Õpikute sõnavara”).

Taas vajavad kirjastaja tähelepanu 5 . kl inimajalugu ja 7. kl muusikaõpetus, kus nimi- ja tegusõnade suhe on u $7: 3$. Võrdluse alusel võiks 4. -5 . klassis optimaalne olla suulisele lähem kahe keelevormi keskmine $6: 4$ ja 7 . klassis kirjalikele tekstidele tüüpiline $65: 35$, mis iseloomustab näiteks 6. kl ajalooõpikut. (Meenutagem, et noorte vabas kirjavahetuses ja uuritud proosas on nimi- ja tegusõnade suhe ligikaudu üks ühele.)

4. Teksti leksikaAlne tihedus Ja MõttekUlu KiIRUs. Leksikaalne tihedus (ingl lexical density, LD) osutab teksti arusaadavust lugemise kulus. Muutujat mõõdetakse leksikaalsete ja funktsioonisõnade suhte alusel ja

${ }^{56}$ Reet Kasik, Terminikasutusest ajakirjandus- ja teaduskeeles. Ettekanne „Tekstipäeval 2011” 20.01.2012 Tartu Ülikoolis. 
seda mõjutab väga tugevasti nimisõnade osatähtsus. ${ }^{57}$ Leksikaalse tiheduse ja lause pikkuse suhtest on kirjanduses järeldatud teksti mõttekulu kiirust (vt allpool).

Leksikaalset tihedust on mõõdetud mitut moodi. Enim näikse viidatavat Jean Ure'i (1971: 445) lihtsale valemile, mille toel Ure mõõdab leksikaalset tihedust kui leksikaalse tähendusega sõnavormide osatähtsust sõnede hulgas. Kõrvale jäetakse funktsioonisõnad (kaassõnad, sidesõnad, asesõnad ja asemäärsõnad, abimäärsõnad ja abiverbid, tekstipartiklid, mitmes keeles ka artiklid), mis ei kanna sisu ja teevad teksti lõdvemaks.

Halliday (1989: 72-79) jpt ${ }^{58}$ nimetavad lekseemivormide osatähtsust teksti infotiheduseks. See on teksti tiheduse kolmest kontseptsioonist lihtsaim. Täpsemaks peab Halliday (ibid.) leksikaalsete üksuste keskmist hulka lausungi (s.o elementaar- või osalause ja lauselühendi) kohta. Kõige täpsema tulemuse saamiseks soovitab ta määrata ka kasutatud sõnade sagedusjärgu ja kombineerida tihedusarvutustes lausungi keskmist lekseemivormide üldarvu tuttavate ja tundmatute lekseemide üldarvuga. Tekstilekseemide sagedusjärku on Eestis ja Soomes mõõdetud sõnavara ulatusena (vt Pajupuu jt 2010).

Pirjo Karvoneni (1995: 190) uuritud soome õpiteksti leksikaalne tihedus on Ure'i tähenduses 72. Võrdluseks toob Karvonen välja, et soome teadusteksti tihedus on väiksem - 58. ${ }^{59}$ Michael Stubbs (1996: 73) on korpuste analüüsil saanud inglise kirjalike žanrite leksikaalse tiheduse piirideks 40-65, kusjuures kõige tihedam on aimeraamatute, teadusartiklite ja haldusdokumentide tekst. Teisal on nelja valdkonna teaduskirjutiste tiheduspiirideks inglise keeles saadud 52 (rakenduspsühholoogias) kuni 68 (füüsikas) (Bloor 2004: 90). Võrreldes näiteks kaassõnade kui funktsioonisõnade eeldatavat määra analüütilises inglise keeles ja tugevasti sünteetilises soome keeles, on keeliti leitud väärtuste suhe ootuspärane.

Paraku ei ole lausungite (osalausete ja lauselühendite) hulka eesti varasemas žanrimaterjalis teada. Leksikaalne tihedus arvutati seepärast

\footnotetext{
${ }^{57}$ LD ja nominaalsuse korrelatsioon on väikses võrdlusaluses žanrivalimis väga tugev $(r=0,875)$. Determinatsioonikordaja järgi mõjutavad seda seost enim nimisõnad $(d=0,765)$. Kirjalike žanrite LD hajuvus on samas väike $(6,02)$, kui arvestada, et kaasatud on ka teismeliste meilid ja ilukirjandus.

${ }^{58}$ Vt viiteid Kerge 2010a.

${ }^{59}$ Ilmselt on see tingitud nimisõnade paratamatult suuremast hulgast; vt üle-eelmist märkust ja arutlusi nominaalsuse kontekstis.
} 
lause pikkuse kohta - sellele suhtele annab tõlgenduse Meriel Bloor (2004; vt allpool). Samuti ei saa eesti ajakirjandus- ja ilukirjanduskorpuse sagedussõnastiku alusel oletada, mis on põhikooli II astme õpilasele tuttav või võõras sõnavara. Varasemast puuduvad ka abiverbide ja abimäärsõnade andmed. ${ }^{60}$ Nii on allpool õpiteksti leksikaalse tiheduse suhteline määr arvutatud Ure'i valemi alusel, kuid nii, et lekseemiks loeti kõik nimi-, omadus- ja tegusõnad ning määrsõnad (v.a asemäärsõnad), funktsioonisõnadeks aga igat liiki asesõnad, asemäärsõnad (sh nii osutavad kui ka küsivad-siduvad), hüüd-, side- ja kaassõnad. ${ }^{61}$ Saame küll žanrivõrdluse, kuid mitte eesti žanrite leksikaalse tiheduse täpset määra. Leksikaalse tiheduse näitajad tabelis 6 allpool on seega pisut suuremad kui peaks, kuid süstemaatilises nihkes, st õpiteksti leksikaalse tiheduse suhe võrdlusmaterjali mediaanväärtusega võiks täpsel mõõtmisel olla ligikaudu sama.

Maailmas on mõõdetud ka leksikaalse varieeruvuse astet, mida väljendab lekseemide (eri sõnade) osatähtsus teksti sõnede hulgas (Crawford Camiciottoli 2007: 73). ${ }^{62}$ Katseks eristati ka 7. kl muusika õpitekstis käsitsi kõik funktsionaalsed sõnad (st ka abiverbid ja abimäärsõnad, mida varasemates žanriuurimustes polnud märgendatud). Nimetatud muusikaõpiku leksikaalne varieeruvus on $38 \%$ ja leksikaalne tihedus $67,9 \%$. Kahjuks puudub esialgu võrdlusmaterjal, mis lubaks varieeruvust hinnata ja suhestada. Küll lubab täpselt arvutatud leksikaalse tiheduse arvväärtus oletada sama muutuja väärtuste süstemaatilise nihke ulatust kogu tabeli 6 avaveerus - see on oletamisi 10\% mail.

Leksikaalset tihedust lause pikkuse kohta (tabeli 6 viimane veerg) kommenteeritakse allpool.

Oma lekseemsõnede 76-78\%-ga on õpitekst veidi tihedam kui kolleegide igapäevased töömeilid ja kirjalik monoloog. On raske oletada,

${ }^{60}$ Sõnaliike määrates on abi- ja põhiverbe loetletud eraldi; abimäärsõna on ühendverbi koosseisus loetud eraldi määrsõnaks, kui ta modifitseerib tähendust (nt edasi v tagasi minema), ning verbi osaks, kui tegemist on väljendiga (nt piltlikud alla kirjutama, ette nägema).

${ }^{61}$ Heyligheni ja Dewaele (2002) valemit arvestades on arvsõnad jagatud kolme ossa: põhiarvsõnad nimisõnadeks, järgarvsõnad omadussõnadeks (lekseemid) ja asearvsõnad asendussõnadeks.

${ }^{62}$ Kirjanduses valitseb suhteline segadus: mida osa autoreid peab leksikaalse varieeruvuse astmeks, nimetavad teised leksikaalseks tiheduseks. Anne Vermeeri (2000) järgi on aga sõnade ja sõnede lihtsuhe üldse suhteliselt ebatäpne näitaja. 
kas see näitaja on eakohane, st kas nt nominaalsuse paratamatus õpikus on õpiteksti suure leksikaalse tiheduse piisav argument.

Tabel 6. Õpiteksti suhteline leksikaalne tihedus võrrelduna osutatud andmetega*

\begin{tabular}{|c|c|c|c|}
\hline Allikas & $\begin{array}{l}\text { Ligikaudne } \\
\text { leksikaalne } \\
\text { tihedus LD }\end{array}$ & $\begin{array}{l}\text { Lause pikkus } \\
\text { SL }\end{array}$ & $\begin{array}{c}\text { Leksikaalne } \\
\text { tihedus lause } \\
\text { pikkuse kohta } \\
\text { LD : SL }\end{array}$ \\
\hline Ajalugu, 5. kl & 77 & 11,8 & 6,5 \\
\hline Ajalugu, 6. kl & 76,4 & 11,6 & 6,6 \\
\hline Muusika, 7. kl & 77,7 & 12,7 & 6,1 \\
\hline Õpikud 2011 & 77,1 & 12 & 6,4 \\
\hline $\begin{array}{l}\text { Teismeliste omavahelised } \\
\text { meilid (Kerge 2010a) }\end{array}$ & 69,1 & $\begin{array}{c}\text { (lausepiir } \\
\text { ebamäärane) }\end{array}$ & - \\
\hline $\begin{array}{l}\text { Töine kollegiaalne meili- } \\
\text { vahetus (Kerge 2010a) }\end{array}$ & 73,2 & 10,1 & 7,2 \\
\hline $\begin{array}{l}\text { Kaplinski romaan (Põld } \\
\text { 2008) }\end{array}$ & 63 & 12,9 & 4,9 \\
\hline $\begin{array}{l}\text { Mittefiloloogidest täis- } \\
\text { kasvanute kirjalik arutlus } \\
\text { (Pajupuu jt 2010) }\end{array}$ & 77,1 & 14,4 & 5,4 \\
\hline $\begin{array}{l}\text { Mittefiloloogidest täis- } \\
\text { kasvanute suuline arutlus }\end{array}$ & 62,2 & 20,2 & 3,1 \\
\hline $\begin{array}{l}\text { Eesti tekst (suuline ja } \\
\text { kirjalik; alus Kerge, } \\
\text { Pajupuu 2010), sh }\end{array}$ & $\begin{array}{l}\text { keskmine } 71,9 \\
\text { mediaan } 71,6\end{array}$ & - & - \\
\hline suulised žanrid & $\begin{array}{l}\text { keskmine } 65 \\
\text { mediaan } 63,6\end{array}$ & - & - \\
\hline kirjalikud žanrid & $\begin{array}{l}\text { keskmine } 75,7 \\
\text { mediaan } 71,3\end{array}$ & $\begin{array}{l}13,8 \text { (Kerge } \\
2003)\end{array}$ & 5,5 \\
\hline $\begin{array}{l}\text { kirjalik monoloog üldse } \\
\text { või õigusaktideta }\end{array}$ & $\begin{array}{l}\text { keskmine } \\
74,6 / 73,8 \\
\text { mediaan } 73,8\end{array}$ & - & - \\
\hline
\end{tabular}

* Kindla žanri andmed pärinevad tabelireas või -lahtris viidatud allikast. LD - leksikaalne tihedus (ingl lexical density), SL - lause pikkus sõnedes (ingl sentence length). 
Meriel Bloor on andnud kirjaliku teadusteksti siingi uuritud muutujate, lause pikkuse ja leksikaalse tiheduse suhtele omapärase tõlgenduse. Ta jagab tekstid mõtte kulgemise järgi kiireteks ja aeglasteks (fast text versus slow text). Aeglased tekstid kirjeldavad näiteks uurimisprotseduure ja kaasavad seejuures üksikasju, pakuvad näiteid ja põhjendusi. Kiired tekstid eeldavad lugejalt kitsamat asjatundmist ja meetoditega kursisolekut, ei paku näiteid ega õigusta uurimise kulgu. Mida pikemad laused ja väiksem leksikaalne tihedus, seda aeglasema kuluga on tekst. (Bloor 2004: 90-96)

Kui nimetatud muutujate selline seos ka õpikute puhul paika peab (vt eespool tabeli 6 viimast veergu), siis on uuritud Avita õpikutekst üldiselt suhteliselt kiiresti kulgevate liigist: leksikaalse tiheduse keskväärtus lause pikkuse kohta on tabeli täiskasvanutekstides 5,2, varem uuritud kirjalikus tekstis 5,5, õpikutes aga keskmiselt 6,4. Õpikus kulgeb tekst ligi kolmandiku kiiremini kui nt Kaplinski proosas ja kaks korda kiiremini kui suulises suhtluses, kuid siiski umbes $10 \%$ aeglasemalt kui täiskasvanute töömeilides.

Bloori (2004) tulemused juhivad aga igal juhul tähelepanu olulisele seigale: lause lühidus ei ole tingimata voorus ja saab siinkohal teksti tihedusega seostatud tõlgenduse. ${ }^{63}$ Taas tõuseb fookusesse nii lausesüntaksi ja tekstiseoste uurimise tarve kui ka sõnastuse kvalitatiivne analüüs, mis selles uurimuses jääb puudu: kui palju on lausetes üksusi (osalauseid, lauselühendeid), kuidas on nad üksteisega seotud, kuidas tuuakse sisse terminid jms, mida eespool nominaalsuse kontekstis vaid põgusalt puudutati.

5. ÕPIKUTE SÕNAVARA iseloomustatakse järgnevas sõnavara rikkuse võrdleva mõõtmise kaudu, seejärel aga õpikukaupa mitmesuguste sõnakasutuse tunnuste järgi, nagu sõnade korduvus, võõrsõnade määr ja iseloom jms, mida illustreerib kindla õpiku näitestik ja toetavad võrdlused.

${ }^{63}$ Teksti kulgu võib küll mõõta, kuid tulemus nõuab alati kvalitatiivseid argumente. Kirjeldav statistika üldistada ei luba ega ütle napis valimis üldse kuigipalju. Mõned arvutused siiski tegime. Kaheksas uuritud žanris on negatiivne korrelatsioon leksikaalse tiheduse ja lause pikkuse vahel keskmiselt tugev $(-0,59)$ ja sama kordaja on oluline $(-0,34)$ ka seni avaldamata 38 asjaliku žanri valimis, st mida pikem on lause, seda lõdvemaks võib osutuda tekst. Huvitaval kombel ei ole aga mainitud taustavalimis mingit olulist korrelatsiooni lause pikkuse ja sidesõnade määra vahel $(r=0,14)$. Teema väärib eraldi süvenemist. 
5.1. SõnaVARA RIKKUS seostub žanriomaste keelevahendite valdamisega, kuid ka nende omandatavusega. Kui näiteks hinnata õppija arengut, siis on tähtis tema sõnavara rikkuse indeksi kasv ajas. Kui võrrelda eri žanreid, siis on võimalik näidata, milline neist on sõnavaralt mitmekesisem. Kui aga hinnata õpikut, peaks lähtuma teisest vaatenurgast: indeks ei tohiks olla mitmesuguste suuliste ja kirjalike žanrite keskmisest suurem, sest kui sõnad tekstis piisavalt ei kordu, on neid raske meelde jätta.

Sõnavara rikkuse arvutamiseks on valemeid palju (vt Vermeer 2000). Kõige vähem sõltub tulemus uuritava teksti mahust Uberi indeksi puhul, mida on varem eesti tekstide uurimiseks ka kasutatud (vt Pajupuu jt 2009, 2010):

$$
\left.\mathrm{U}=\left({ }_{\log } \mathrm{N}\right)^{2}:{ }_{\log } \mathrm{N}-{ }_{\log } \mathrm{V}\right),
$$

kus $N$ on sõnede arv ja $V$ eri sõnade arv (nt poisile ja poisiga on kaks sõnet, kuid üks sõna).

Uberi indeks üksi ei osuta siiski õpiku puhul kõike olulist. Kui näiteks omandamisväärsed sõnad küll korduvad, kuid ei ole tekst-tekstilt esile toodud ja õpikus puudub neid sisaldav tähestikuline sõnastik, siis võib meelde jääda (korduv või eriline) foneetilis-graafiline sõna ja olenevalt tema tüvevariantide ja vormide sagedusest ka selle sõna grammatika, kuid ei saa olla kindel sõna tähenduse omandatavuses. Seepärast peaks tulemusi selgitama õpiku üldise vaatluse toel (vt osa 6).

Tabelis 7 on õpitekstile võrdlust pakkuda vähe, sest sõnavara rikkust on seni mõõdetud piiratud hulga žanrite puhul (mittefiloloogidest haritlaste asjalikud žanrid, vt Pajupuu jt 2010; Kaplinski tööd, vt Põld 2008; kolleegide omavahelised meilid, vt Kerge 2010a).

Sõnavara rikkus on 6 . klassi ajalooõpikus võrdne täiskasvanute kirjaliku keelekasutuse keskmisega ja lähedal esseede keskmisele. See lubab oletada, et sõnad ei kordu õpikus liiga sageli (nagu suulisele kõnele omane) ega ka õpilase jaoks liiga harva (nagu täiskasvanute tekstides, mil õpieesmärk puudub). Kuna Uberi indeks U arvutatakse sidusas tekstis, siis 4. klassi muusikaõpiku nappi e-materjali selle poolest taas uurida ei saanud.

Tähelepanu vajavad taas 5. kl inimajalooõpik ja 7. kl muusikaõpik, mille sõnavara rikkus ületab täiskasvanute kirjalikke žanreid u 1,2 korda ja kõiki tekste veidi enam. See osutab vajadust analüüsida sõnavara kvalitatiivselt. 
Tabel 7. Õpiteksti sõnavara rikkus võrrelduna osutatud andmetega

\begin{tabular}{|l|c|}
\hline Allikas & $\begin{array}{c}\text { Sõnavara rikkus } \\
\text { (Uberi indeks) }\end{array}$ \\
\hline Ajalugu, 5. kl & 32 \\
\hline Ajalugu, 6. kl & 27,3 \\
\hline Muusika, 7. kl & 33 \\
\hline Õpikud 2011 & 30,8 \\
\hline $\begin{array}{l}\text { Kaplinski romaan (Põld 2008) } \\
\text { Töine meilivahetus (Kerge } \\
\text { 2010a) }\end{array}$ & 27,9 \\
\hline $\begin{array}{l}\text { Mittefiloloogidest täiska...... } \\
\text { nute esseed (Pajupuu jt 2010) }\end{array}$ & 24,9 \\
\hline $\begin{array}{l}\text { Mittefiloloogidest täiskas- } \\
\text { vanute suulised ettekanded } \\
\text { (Pajupuu jt 2010) }\end{array}$ & 29 \\
\hline $\begin{array}{l}\text { Täiskasvanute kirjalikud } \\
\text { žanrid }\end{array}$ & 23,1 \\
\hline Täiskasvanute tekstid & 27,3 \\
\hline
\end{tabular}

Allpool vaadatakse just kahe tekstimuutujatelt kriitiliseks osutunud õpiku sõnavara nii lekseemide tekstisageduse ja võõruse järgi kui ka visuaalselt (st sõnad, mis on otse õpitekstis esile tõstetud või peatüki juures ja õpiku sõnastikus välja toodud).

Lõpuks peatutakse eraldi 4. klassi muusikaõpikul, mille eripära ja e-käsikirja laad ei lubanud sidusa teksti muutujaid uurida.

\subsection{ERISÕNAVARA, NIMED, TEKSTITÖÖ}

Erialade põhiterminoloogia tundmine vähemasti passiivselt on vajalik, et orienteeruda tänapäeva maailmas ja infotulvas (Puksand 2005). Tiiu Erelti väitel ei saa samas üld- ja oskussõnavara vahele tõmmata selget piiri. Ühelt poolt kasutab oskuskeel uute mõistete loomisel ja laenamisel tähistajana üldsõnavara elemente või täpsustab üldsõnade tähendust, teiselt poolt saavad mitmed erialamõisted üldtuntuks ning sõnad muutuvad üldsõnavara osaks. (Erelt 2007: 615)

Üks viimase protsessi tegureid on just üldhariduses omandatav oskussõnavara, mis tagab nii kultuuriomase maailmapildi kaasaegsuse kui ka 
üldkeele moodsuse. Kui inimese maailmapilt ei ole piisavalt moodne ja esimese keele pagas sellele vastav, on tal väga raske ka muude keelte tekste mõista.

Terminite jm uute sõnade omandamine nõuab nende korduvust ainega tutvumise, selle mõistmise, kinnistamise ja kordamise käigus. Jaan Miku järgi peaks termin, mille omandamist õpik taotleb, õppimise kulus ette tulema umbes 7 korda. Sel taustal on siin-seal vaadeldud ainekirjaoskuse suunamist mitmekesise tekstitöö kaudu, mis terminikasutust harjutab.

Helin Puksandi järgi on oskuskeele osatähtsus õppetekstides aineti ja klassiti erinev. Näiteks 4.-6. klassi eesti keele õpikud koosnevad peamiselt ilukirjanduslikest tekstidest, seega on terminoloogiat neis õige napilt, muude õpikute üks eesmärke on aga tutvustada kindla eriala keelt ning sellest tulenevalt on neis termineid oluliselt rohkem. Oskussõnade määr erineb aga suuresti - väljaspool emakeeleainet on mõnes õpikus oskussõnu peatüki kohta 1,3, teises aga 6,4. (Puksand 2005: 75)

Ainevaldkonna terminid on õpilase jaoks enamasti tundmatud, sest vaid osa neist on igapäevases kasutuses ja viimastegi tähendus on ebatäpne ja hajus nagu üldkeele sõnadel sageli. Terminite puhul on väga oluline just täpne tähendus, mis tingib seletamist. Selgituse võib vahele jätta vaid juhul, kui on kindel, et õpilased seda tunnevad. Samuti peavad terminid muust tekstist selgelt ja arusaadavalt eristuma ja piisavalt korduma. Mida rohkem kordi sõna tekstis esineb, seda paremini see õpilasele meelde jääb. (Puksand 2005: 69 jj) Kõik see juhatab õpikusõnavara analüüsima eraldi nii sageduse kui ka omandamist toetava visuaalse esiletõusvuse ja taasleitavuse tahult.

Tähelepanu vajavad muu hulgas ainekohased isiku- ja kohanimed, k.a võõrnimed (eestikeelsed ja originaalsed võõrkohanimed, võõrisikunimed), ning võõr- ja tsitaatsõnad, mida on raske lugeda, kuid mis on ainega seostuvana olulised. Võrdlust pakub Merike Mägedi uurimus (2003), mille järgi võõrsõnamäär on kõige väiksem luules (2\%) ja kõige suurem teadustekstis $(12,4 \%)$; ajakirjandusteksti puhul on see näitaja $9 \%$ ja nii suureks teeb valdkonna keskmise kultuuriajakirjandus kui kõige võõrsõnalisem tekstikogum (võõrsõnu 17,5\% sõnedest).

\section{5. klassi inimajaloo õpik}

Õpiku kolme elektrooniliselt kättesaadava peatüki õpitekstis esinevad igas peatükis 8-11 korda tekstide põhiteemaks võetud isikute nimed (Coco 
Chanel, Astrid Lindgren, Lydia Koidula) ja nende osad. Ainele iseloomulikult leiab 5 ja enam korda ajasõnu aasta (15) ja sajand (6). Inimest ja inimrühmi tähistavad inimene (5), rahvas (5) ja eestlane (7), laps (30), isa (5), vanemad (5) ja täiskasvanud (6), naine (24) ja mees (5). Inimese elupiire ja -etappe, rolle, tegevusi ja nende tulemusi märgivad sündima (6), surema (6), lapsepõlv (5), kirjanik (6), töötama (6), kirjutama (5), ajaleht (6), luuletus (6). Samal määral korduvad ka käändumatu omadussõna eesti ja omadussõna suur. Ülejäänud korduvad sõnad kannavad grammatilist tähendust.

Võõrsõnu on analüüsitava õpiteksti sõnade hulgas $2,5 \%$, mis on ilukirjandusele lähedane väike määr. Võõrtüvesid on veel vähem, vaid 1,9\% need korduvad (nt tsaar sõnades tsaaririik ja -valitsus, kultuur liitsõnades kultuuripärand ja -tegelane, poliit- sõnades poliitika ja poliitiline) ning on enamasti väga sagedaste hulgast (harvemad on nt varietee või daam) või on peatükkide all üle seletatud, nagu feminism ja pseudonüüm. Seletused antakse peale võõrsõnade ka ühendite eesti rahvuslik ärkamisaeg ning avalik arvamus puhul - viimast seletab terve alapealkirjastatud tekst Lindgreni isikuga seotuna.

1-2 korda esinevaid sõnu on inimajaloo õpitekstis $96 \%$, kuid 7 ja enam korda esinevaid 3,7\%. Keelendite omandamise aspektist pole aga oluline sõnade, vaid ka sõnatüvede korduvus. Omatüvede kordumine eri vormis ja kontekstis aitab sõnavara põhiüksusi kinnistada ja sõnamoodustuse süsteemi omandada. Selles mõttes võib õpikuga rahule jääda. Näiteks esineb ela-tüvi tegusõnana 2 korda, kuid kordub 8 korda lihtsõna elu mitmetes vormides ning veel 17 korda liitsõnades: eluaasta, -järk, -kaaslane, -koht, -lugu, -tingimused, abielu, ühiskonnaelu. müü-tüvi esineb sõnades müüma, müügil, müüja ja müüjanna; kiri- : kirja-tüvi esineb 7 sõnas; eesliidet ebakorratakse 3 sõnas ja üle-tüve kasutatakse kolmes tähenduses; abstraktse õiguse kõrval esineb ka omadussõna õiguslik jne.

5. klassi ajalootekstide sõnavara on seega ühest küljest suures osas lastele varem tuttav, mis soodustab aine omandamist - mõistete vahel luuakse uusi seoseid ning neid seostatakse uute kontekstide ja ajalooliste isikutega. Teisest küljest pakutakse emakeele tüvesid mitmekesiselt. Sõnade väike korduvus (suur sõnavara rikkuse indeks) ei ole järelikult tegelik probleem.

Õpikus on kokku 44 peatükki. Termineid seletatakse nii tekstis kui ka eraldi teksti järel. Tekstis on 140 terminit (neist 18 lisalugemiseks 
mõeldud tekstides) ja teksti järel 135 (ilmselt tuleb need selgeks õppida). Õpiku sõnastikus on termineid 136, lisaks mõned ajaloosündmuste, organisatsioonide jm nimetused. Iga peatüki kohta on keskmiselt 3,1 terminit, kuid õppeaasta igas tunnis peaks läbi võtma umbes 1,3 peatükki ja selgeks saama ligi 4 terminit. $^{64}$

\section{7. klassi muusikaõpik}

Õpik vajab eritähelepanu - oleks raske leida ainet, kus õpitekst oleks võrdselt võõr- ja tsitaatsõnarohke: koos originaalsete mitte-eesti pärisnimedega moodustavad nad kõnealuse aine õpikus 12,3\% sõnedest, mis on Mägedi (2003) järgi teadusteksti tase. Seejuures on ülekaalukalt tegemist muusika oskussõnade ja aines oluliste nimedega - õpik eeldab isikute ja kohtade seostamist mõistetega, sõnade sisu ja vormi omandamist. Eriti keerukaks teeb olukorra see, et paljud struktuurivõõrad oskussõnad on ka kasutusvõõrad, ka haritud täiskasvanule tundmatud, nt bharata, burdoon, gamel, gamelan, gamelanmuusika ja -orkester, kathakali, klezmer, korroborirituaalid, makaam, sanskriti, shamisen, tabla, tampura, tšuringa, või vähemalt õpilasele uued, nt folkloorne, ideaalarv, imiteerima, improvisatsioon, instrument, instrumentaalkoosseis, interpreet, intonatsioon, judaism, kabuki, kabukiteater, kammertoon, kimono, kolonist, konfutsianism, latiniseeritult, luuletraditsioon, meloodiamudel, mošee, mütoloogiline, müüt, müütiline, nasaalne, no-teater, nüansirikas, pantomiimilaadne, partii, pentatoonika, ramadaan, rekvisiit, religioosne, sümbol, sümboliseerima, sünagoog, šintoism, šamanism, zen-budism, tonaalne, veedahümn, vokaalmuusika; lisaks hulk pillinimetusi jne. Peale võõrterminite sisaldab õpik palju abstraktseid muusika jm kultuuri omatermineid. Peaaegu kõik loetletud sõnad on (vähemalt oma käändevormides) ka keskmisest pikemad.

Juba üle 30 aasta eest on Viivi Maanso (1979: 54) hoiatanud, et õpiku võõrsõnade keerukusest ja üldkeelekaugusest kõneleb see, kui osa neist pole esitatud õigekeelsussõnaraamatus (ÕSis) ega võõrsõnade leksikonis. Tundub, et teadlane on asjatundjana võõrsõnade analoogilise määra ja vähema kasutusvõõrusega erialateksti puhul paremas olukorras kui analüüsitava muusikaõpiku kasutajad oma 13-14 eluaasta napi keelekogemuse juures. Samas juhib töövihik muusika kuulamisel võõrsõnu aktiveerima ja kasutama (nt kirjeldama tempot, dünaamikat ja nende

${ }^{64}$ Põhikooli II astmes on ajalugu 1 tund nädalas (35 t aastas); vt PRÕK 2011. 
muutusi), samuti sõnu seletama, kindla kultuuriga seostama, neid sõnu tähtedest rekombineerima jne.

Sõnade keskmine korduvus on vaatlusaluses õpikus 2,1 (nt 5. kl ajalooõpikus on see sama ja 6 . kl ajalooõpikus ligi $15 \%$ suurem - 2,6) ning sedagi keskmist näitu suurendavad e-materjalis 35 korda esinev sõna muusika, 15-17 korda kasutatud kohanimed Hiina, India jms. 1-2 korda esinevaid sõnu on uuritud tekstis $86 \%$, Jaan Miku soovitatud 7 korra piiri ületab aga 1,2\% sõnu (etendus, kultuur, laul jms, k.a eespool nimetatud). $\mathrm{Nt} 5$. klassi ajalootekstis on viimaste osatähtsus täpselt kolm korda suurem.

Sõnaseletusi peatükkide juures ei ole, kuid kõik muusikaterminid on tekstis poolpaksus kirjas esile tõstetud ja sõnastikus seletatud. Sõnastik sisaldab 131 terminit, s.o keskmiselt 11 terminit iga peatüki kohta ja 3-4 terminit iga ettenähtud tunni kohta ${ }^{65}$. Sõnastikku täiendab vahetult selle ette paigutatud teooriaosa, kus mõisted on 8 leheküljel avatud ja suhestatud skeemide jm (nt klaviatuuri-) jooniste, rütmi- ja muusikanäidete abiga ning toestatud mõistetevaheliste viidetega.

Õpivarakomplekti ülesanded suunavad keelt mitmel moel teadvustama ja kasutama, nt koostama loetu kohta küsimusi, lahendama pillinimetuste ainel ristsõnu, koostama pikkadele sõnadele rütmiskeeme, mõtlema teatud kõlavärvi kirjeldavaid omadussõnu, kasutama kohanimesid, leidma muusikanähtuste iseloomulikke märksõnu. Ka esitatakse mitut laadi esseeteemasid ja ehitatakse need kohati kindlate terminite ümber, suunatakse kirjutama tabeliveergu lühiarvamusi kuulatud muusikapalade kohta jms. Ülesanded soosivad loovat ja individuaalset muusikaga suhestumist, nagu võimalus muusikat (nt suurvorme) kuulates oma tekkivaid mõtteid vabas vormis kirja panna.

\section{4. klassi muusikaõpik}

176 lk õpiku 27 peatükki mahub 88 nootide ja sõnadega laulu, mille sõnavara ei saa vaadelda õpitekstidega samal alusel.

Kahjuks ei ole harvad sidusad tekstid sattunud kirjastuse e-variantiviimases on 1925 sõnet õpiteksti, mis jaguneb 309 üksuseks (igaüks 6 sõnet). Peamiselt on tegu üksikjuhiste, loendite ja pealkirjadega, kuid need sisaldavad ka termineid. $\mathrm{Nt}$

${ }^{65}$ Põhikooli III astmes on muusikaõpetust 1 tund nädalas (35 t aastas); vt PRÕK 2011. 
(9) Loe teksti ja plaksuta rütmi kaasa.

Loe teksti ja mängi rütmi vahelduvate kätega kehapillil.

Loe mõttes teksti ja mängi rütmi kehapillil.

Mängi peast rütmi kehapillil.

Esitage rütmimängu ka kolmehäälse kaanonina.

Laulusõnad õpetavad eri aegade kirjakeelt ja murret (sh nende sõnavara). Juhiste kaudu pakutakse palju korduvat üldsõnavara (vt näiteid). Terminid on suures osas esile tõstetud (näide (10) esindab seda osa tekstist, kus terminid peavad olema selged), esile ei tõsteta noodinimesid, kindlaid helistikke jms. Lugeja jaoks tekstis esile tõstetud terminid on sõnastikus kokku 66 terminit, st ligi 2 terminit peatüki kohta ja 1,4 tunni kohta ${ }^{66}$. Ainele omaselt on neist ligikaudu 70\% võõr- ja tsitaatsõnad (viimaseid on 8 , kuid see on u $12 \%$ õpiku terminitest). Võõrkeeli tutvustavad rohked autorinimed. On ka üks ingliskeelne laul. Laulude sisukorrale on antud (küsitav) tähestikku õpetav lisafunktsioon - pealkirjad on oma algussõna tähestiku järjekorras.

Õpivarakomplekt suunab keelt eakohasel moel teadvustama ja kasutama: kirjutama oma mõtteid muusikast, seletama kõla teket eri pillidel, rütmistama liitsõnu, leidma kindla tähega pillinimetusi, lahendama või koostama teemakohaseid ristsõnu, iseloomustama muusikapalu, kirjeldama pille kodus ja koolis, panema allikate toel kirja heliloojate kohta omandatud teadmisi jm.

6. ÕPIKUTE ÜLDINE VAATLUS. Vaatlus annab visuaalseid andmeid, mis võivad õpikute eespool leitud küsitavaid omadusi mahendada: kui pikad on õpiku tekstid, kuidas tähelepanu köidetakse ja omandamiseks olulist esile tuuakse, mis roll on illustratsioonidel ja pildiallkirjadel jne. Tegemist ei ole kõrvalise, vaid olulise andmestikuga, mis määrab õpilase suhte õpikuga ja õpiku üldise kasuteguri (vt Mikk 2000; Puksand 2005 jm). Lisaks on vaatlusel jälgitud, kuidas õpikomplekt (st õpik koos töövihikuga) üldjoontes suunab keelt kasutama ja teadvustama.

Õpiku kvaliteedi kriteeriumid on Jaan Miku (2000) arvates sisu, jälgitavus ja liigendatus. Viimast käsitletaksegi allpool. Muu hulgas rõhutab Mikk (1991) ka illustratsioonide tähtsust ja tuletab meelde, et 90\% töödeldavast infost võtame vastu silmadega.

${ }^{66}$ Põhikooli II astmes on muusikaõpetust u 1,3 t nädalas; vt PRÕK 2011. 
Lühemad read ja kitsamad veerud teevad üldse, kuid eriti lugemisraskuste, tähelepanuhäirete jms puhul lugemise lihtsamaks (Pedley 2006). Üks silmaliigutus kestab 20-40 ms ja haarab keskmiselt 7-9 tähekohta (kiirus ja ulatus olenevad individuaalsusest ja lugemisvilumusest). Ühtaegu omandatakse juba informatsioon; silm liigub samas aeg-ajalt ka vilksamisi tagasi, nii vasakule kui ka üles. (Rayner jt 2001)

Sellel taustal võib juba enne lähemat vaatlust küsida, kas on õigustatud Avita õpikute lai $(21 \times 25 \mathrm{~cm})$ formaat. Selle maksimaalne veerulaius tähendab siin ligi 100 tähekohta ehk kuni tosinat silmaliigutust; eriti raske on laia veeru puhul heita meenutavat ja kaasamõtlemist toetavat kiirpilku ettepoole (rea algusse või üles). Tegelikult on õpiteksti veerg enamasti kitsam (vt all): serv jäetakse tühjaks või kasutatakse seda illustratsioonideks (fotod, skeemid jm).

\section{5. ja 6. klassi ajalooõpikud}

Mõlemad õpikud on jaotatud kahte raamatusse. Peaaegu kõik peatükid paiknevad kahel paarisleheküljel. Teksti alustab taustavärvi või poolpaksu kirjaga esile tõstetud sissejuhatus, mis 5. klassi õpikus on suhteliselt lühike (keskmiselt 44 sõna 6 real). Teksti liigendusosi ( ca 90 sõna) eristavad alapealkirjad. Põhiteksti valgel taustal tõusevad olulisemad terminid poolpaksus kirjas hästi esile. Muud tekstid pakuvad huvitavat lisateavet ja on eristatud värvilise tausta või ka kaldkirja toel. Põhiteksti kahepoolse joondusega veeru laius varieerub 6-10 sõnani real. Peatükid Iõpevad kordamisküsimustega ja olulisemate terminite taasesitusega. Tekst on rikkalikult (poole kuni kahe kolmandiku ulatuses lehekülje pinnast) illustreeritud nii joonistatud piltide kui ka fotodega, mis toetavad õpiteksti.

Kuigi Lixi järgi on ajalooõpikud (eriti 5. kl) suhteliselt rasked, hõlbustab nende kujundus - lühikesed lõigud ja ülekaalus kitsad veerud lugemist ka neil, kellel on lugemisraskusi.

\section{4. klassi muusikaõpik}

Õpitekst ja muusikapalad vahelduvad, tegevusjuhistes märgitakse pille lühendite või sümbolitega; sümbolid juhivad ka muid korduvaid tegevusi (nt muusikapala kuulamine, fonogramm, õpime kuulmise järgi ...). Üsna ilmselt vajab selline ökonoomne sümbolite süsteem harjumist, kuid töö käigus on võimalik naasta seletuste juurde õpiku algul. 
On kaht tüüpi õpitekste: väga üksikud sidusad teabetekstid pikkusega 30-100 sõna ning kindlateemalise loendina paigutatud informatiivsed lühilaused seotuna fotode, skeemide ja tegevusjuhistega; $\mathrm{nt}$

(10) Muusikas on helidel erinevad kõrgused.

Helisid kirjutatakse nootidega.

Noodist saab laulda noodi- ja astmenimedega.

(ja veel kolm lauset koos relatiivse noodisüsteemi käemärkidega, mis katavad lehekülje). Lehekülje lõpetab töövihiku ülesannet täitma suunav kastike.

(10a) Laula ja näita käemärke.

- TV ül 2

Napi õpiteksti veerulaius on u 10 sõna (ligikaudu 70 tähekohta), mis tehniliselt väheosavat lugejat ei toeta. Seejuures on nii laia veergu vähegi pikemate tekstide vähese hulga kohta suhteliselt enam kui 7. klassi õpikus. Suurendatud lõiguvahet ega taandridu lugemist hõlbustamas ei ole; lõigueristus jääb tühja realõpu kanda. Neid puudusi mahendab asjaolu, et tekstid on valdavalt lühikesed ja illustratsioonide (skeemide, jooniste, fotode) tugi rikkalik.

\section{7. klassi muusikaõpik}

Õpitekst vaheldub lauludega. Tekstiveerg on u 10 sõna lai, mis selles eas peaks enam sobima (kuid pole tegelikult ka vilunud täiskasvanule soodne). Sellest kitsamat veergu on kasutatud suhteliselt enam kui 4. klassi õpikus. Lehekülgede äärtel muusikariistu iseloomustava teksti kõrval on joonised või fotod, mis veergu kitsendavad. Kultuuritekstide juures on mitmesugusel viisil paigutatud fotosid; õpitavad regioonid on osutatud kaardil. Laule saadavad meeleolufotod. Solfedžoõpinguid toetavad selged skeemid ja ülevaatetabelid.

Ka selles õpikus võib eristada valgel taustal põhiteksti ja värvilisel taustal kursiivkirjas lisateksti. Tekste on eri pikkusega, loetavust toetab selgitustega termininimestike kohatine paigutamine õpiteksti asjakohaste lõikude vahele. Lõigud on ebaühtlase pikkusega - on nii 3-4 reaga lõike kui ka oluliselt pikemaid (15-16 rida). Taandread puuduvad, kuid pikkade lõikudega tekstis ei erine lõiguvahe silma jaoks selgel määral reavahest. Nendest vigadest hoolimata toetab loogilise skeemiga õpik üldjoontes 
lugejat ja raamatut käes hoides ei tundu hästi liigendatud ja illustratsioonidega toetatud tekst nii raske, kui keeleanalüüs näitab. Kas õpik ei ole liigagi kirju, see vajab asjatundja otsust.

\section{Arutelu ja järeldused}

Teadlased on seisukohal, et ehkki mõõdikuid kasutatakse enim toimetamissoovitustes, on nende loomise mõte ikkagi teksti raskusastet ennustada. See ennustatavus kehtib kahes alas: loodava või kasutatava teksti sidumine kindla raskusastmega ja valmis teksti lugemiseks sobiva vanuse oletamine. (Harrison, Bakker 1998: 124) Mõlemat on õpiku kontekstis vaja. Seega on teksti jälgitavuse ja mõistmiseelduste mitme tahu uurimise tulemused asjatundliku õpikukirjutaja tööriist ning peaksid tekstiuurijate kõrval huvitama nii autoreid kui ka kirjastajaid.

Uurimus näitab õpiteksti raskust suhteliselt sõltumatu faktorina, mis näib seostuvat lugemisoskuse tehnilise küljega (vt arutlusi muutujate üle allpool). Avita põhikooli II astme õpikud siin peaaegu ei erine 2003. a väljaspool emakeeleainet uuritutest; erinevused ilmnevad pigem õpikute vahel. Raskeks võib pidada teistest kõigiti eristuvat 7. kl muusikaõpikut, selle raskusastet pole aga hetkel millegagi võrrelda. Raskusastmearvutused tõid esile ka sõnavara kvalitatiivse uurimise tarbe. Ilmnes, et muusikaõpetuse terminoloogia on kirjakeele igapäevasest keskmest igal juhul väga kaugel, seostuvalt kaugete kultuuridega aga eriti. Allpool üritame seda olukorda 7 . kl näitel mõtestada.

Teise faktorina võiks käsitada arusaadavuse hõlpsust, mida iseloomustavad kolm tugevasti korreleeruvat muutujat. Nominaalsus toob esile mõistelise tiheduse ja vastandub verbilisusele kui kujutatavaid olukordi laiemalt peegeldavale tekstikomponendile. Žanreid eristab väga selgesti nimisõna- ja tegusõnavormide seni kirjeldamata suhe: see on igapäevastes tekstides (ilukirjanduses ja noorte argisuhtluses) ligikaudu $1: 1$, uuritud žanrite keskmisena 1,5:1, õpikutes aga 1,8: 1 (s.o kirjaliku teksti keskmisel tasemel) või isegi $2,3: 1$. Kuigi nimisõnu on aime- ja õpitekstis paratamatult enam, nagu selgitab Karvonen (1995), väärib 2,3-kordne erinevus kindlasti kvalitatiivset tähelepanu. Leksikaalse tiheduse eristusjõud on selgelt napp: eelmainitud igapäevatekstid on uuritud žanrite keskmisest $10 \%$ lõdvemad, õpikud aga on igapäevatekstist u $20 \%$ ja uuritud žanrite keskmisest u 10\% tihedamad. Muutuja väärib edasist kvalitatiivset 
tähelepanu teksti kulu kiiruse tegurina (vt Bloor 2004), mis annab pikematele lausetele eeliseid ja suunab edaspidi uurima teksti süntaksit (sõnastust), eriti aga sidumist. Formaalsus näitab väljendustäpsust, millega kooliajal tuleb harjuda. Teismeliste erameilidest on Avita õpikute F-indeks 1,7-1,9 korda suurem ning õpikute keskmine ületab täiskasvanužanreid u 35\%. Verbilisuse ja adverbilisuse kasv selgituste ja näidete kaudu võiks seda näitajat täiskasvanulikku täpsust kahjustamata kahandada nt kirjaliku keskmise tasemele, mida õpikud ületavad kuni $25 \%$.

Sõnavara rikkuses ja esitusviisis on õpikuti olulisi erinevusi. Sõnavara rikkust näitav U-indeks on õpikutes $20 \%$ suurem haritud täiskasvanute tekstide keskmisest. Keskmiselt on õpiteksti sõnavara u 10\% mitmekesisem kui Kaplinski romaanis ja ligi 25\% mitmekesisem kui töösuhtluses, kus terminid peaksidki sageli korduma - oletamisi peaks nad samal moel, ehkki teisel põhjusel korduma ka õpikutes. Sõnad korduvad uuritud õpitekstis 2,1-2,6 korda, kuid suuresti erineb 1-2 korda ettetulevate sõnade määr, mis taas väärib nii toimetajate kui ka kooliealiste sõnavara uurijate tähelepanu. Termineid tuleb tunni kohta omandada 4. klassis 1-2 ja hiljem 3-4.

Praegused õpikud ei erine seega üldjoontes 2003. aastal väljaspool emakeeleainet uuritutest oma raskuselt, kuid on selgesti täiskasvanulikud kõiges peale tekstide pikkuse ja esitusviisi. Õppimise tõhusust suurendab õpikute nüüdne ilme ja kujundus, nt illustratsioonide rohkus ja paranev kvaliteet, üksiktekstide paigutus, eristus ja suhteline lühidus, info jagamine mitut liiki teksti vahel, sh fotoallkirjade informatiivne laad jms, mis näib olevat ajaga muutunud süsteemseks.

Avita õpikute formaat on aga ebatavaliselt lai ja paiguti on seepärast ka veerud silmale liiga laiad. Kohati võib ette heita selge lõigueristuse (taandridade või selgesti suurendatud lõiguvahe) puudumist, kuigi Emakeele Seltsi keeletoimkond on just õpetajate algatusel selle tähtsusele tähelepanu juhtinud ${ }^{67}$. Muus osas toetab kujundus õppimist ja mahendab teksti suhtelist raskust. Ainekirjaoskust suunavad kõik õpikomplektid teadlikult ja mitmekülgselt.

4. klassi muusikaõpik on eakohane, muusika ja musitseerimise juurde praktiliselt, k.a rohkete skeemide ja fotode toel, suunav tugimaterjal, kus õpilane puutub kokku ka riimiga, eri aegade kirjakeele ja murretega ning

${ }^{67}$ Vt Krista Kerge, Tiiu Erelt, Emakeele Seltsi keeletoimkond soovitab. - Keel ja Kirjandus 1996, 2, 114-117. 
mitmest kultuurist pärineva nimevaraga. Paari helilooja nimed saavad muusikanäidete kõrval eakohase lühidusega (40-100 sõnaga) ka sõnalise sisu. Termineid - aineomaselt enamasti võõr- ja tsitaatsõnu - õpitakse või kinnistatakse aasta jooksul sadakond, neist 2/3 (uued) on esitatud sõnastikus.

7. klassi muusikaõpikus on hästi illustreeritud ülevaade muusikariistadest ja nende kõlast üksi või ansamblis ning muusikast kaugete kultuuride osana. Komplekti ülesanded suunavad otseselt keelega tegelema, seda teadvustama ja kasutama. Väga rikas on pakutav pilt eksootiliste kultuuride ilmingutest ja nähtustest, eluviisidest ja muust, mille keskele muusika on asetatud ja mis toob kaasa ka täiesti uue sõnavara.

Keelelt on õpik raske, kuid analüüsi tulemuste tõlgendamine oleneb kahest asjast: (a) kuivõrd suudab õpetaja tunnis sama materjali koos terminitega elavdada ehk uut sõnavara kogemusega katta ning (b) mida peab õpetaja ainetulemuste hindamiseks kontrollima.

Kui 7. kl õpikut võtta muusikataju tausta loojana ning kultuurilugemikuna, mille tunnid suudavad huvitavaks teha, siis võib keerukat keelt käsitada midagi täiesti uut õppiva täiskasvanu rolli eelkajana. III kooliastme muusikatundide üheksa õppetegevuse hulgas (Urbel 2010) on vaid üks, kus õpitekstis pakutud teadmisi ja termineid otseselt vaja läheb (vt siin kursiivis esile tõstetud): isiklike, põhjendatud seisukohtade avaldamine muusika kuulamisel, tuginedes muusika väljendusvahenditele ja oskussõnavarale. Rõõmustavalt on õpiväljund tekstiline (argumenteeritud seisukohtade avaldamine) ja seda nõuavad õpikomplekti ülesanded tihti. Ka hindamise tahke on aines väga palju: nendena arvestatakse ,laulmist, pillimängu, muusikalist liikumist, omaloomingut, muusika kuulamist ja muusikalugu, muusikalist kirjaoskust ning ka õpilase aktiivsust, tunnist osavõttu, hinnangut enese ja kaasõpilaste osalemisele ning saavutustele õppes" (Urbel, samas), millest õpitekstiga haakub otseselt vaid muusikalugu.

5. ja 6. klassi ajalooõpikute uurimistulemused toovad esile autorite individuaalse stiili. Kui arvestada, et tegemist on sama kirjastuse sama toimetusega, näib uuritu põhjal, et kaasautori olemasolu aitab 6. klassi õpikus leida eakohaselt sobiva koodi, s.o sobiva vahekorra endale tuttava oskuskeele jm täiskasvanule harjumuspärase ning lastele õppimiseks sobiva sõnastuse vahel. Seda 5. klassi õpiku ainuautor (kes on ka 6. kl õpiku kaasautor) üksi ei taba. Samas mõjutab keelevalikuid ka temaatika: 
5. kl mitmeti raskem tekst osutus näiteks sõnavara kvalitatiivse analüüsi järgi suhteliselt lihtsaks, lihtsa tekstiga 6. kl õpikus on aga terminoloogia raskem. Kuigi õpikukujundus toetab aineõpet igati mõlemas klassis, tasub mõelda mitme autori kaasamisele, mis küsitavatel juhtudel seob mitme inimese stiilitunde.

Uuritud muutujate kohta võiks oluline olla järgmine.

Parameetrite korrelatsioon on loomulikult väga tugev $(r=0,9 \ldots 1)$, kui üks neist on teise põhitegur (nt nimisõnasagedus formaalsuse defineerimise alus) või määravad kummagi väärtuse suuresti kattuvad tegurid (nagu sõnaliigisuhted formaalsusastme ja leksikaalse tiheduse). Ka näiteks see, et kirjaliku teksti leksikaalset tihedust mõjutavad ennekõike nimisõnad ( $r=$ 0,946 ja $d=89 \%$ ) kui viitejõuline ja põhiliselt teemat kandev sõnaliik, on selle parameetri mõõtmise ideesse sisse kirjutatud. Nii ei ole faktoranalüüs isegi vajalik, kuid tuleb rõhutada, et ka sarnasel alusel muutujad näitavad samas teksti jälgitavuse eri tahke ja eristavad tekste ise tugevusega.

Teisalt ei ole tingimata üheselt määratud ka see, kui palju kindla mõõdiku eri tegurid tulemust mõjutavad. Näiteks ei saa teiste keelte alusel eeldada, et omadussõnu on žanriti keskmiselt 5-6\% (mediaan 5) ja et need ei mõjuta väljendustäpsust (F) pea üldse ( $d=0,006$ ehk $0,6 \%)$, samal ajal kui adverbide vastandmõju F-ile on väga suur $(r=-0,908, d=0,824) .{ }^{68}$ Nimisõna(vormide) sagedus mõjutab determinatsioonikordaja järgi samas väga tugevasti mitmeid parameetreid, kuid see ei tähenda nende määra automaatset tingitust. Õpiteksti nominaalsust saab, nagu öeldud, vähendada lauseliste määratluste, eriti aga selgituste osatähtsust suurendades ning sel moel rohkendades verbide ja adverbide hulka, millel on vastavalt keskmine või väga tugev vastassuunaline mõju (nt $\left.r_{\text {Nom : Adv }}=-0,875\right)$. See omakorda vähendab veidi väljendustäpsust (F), kuid kasvatab teksti selgust ja aeglustab veidi teksti kulgu $\left(r_{\mathrm{F}: \mathrm{h}}=-0,394\right.$, oluline). Tähtis on aga, et teksti esmase arusaadavuse taotlus ei viiks ilmselge lihtsustuseni. Loomuliku täiskasvanuliku väljenduslaadiga tuleb hakata varakult harjuma.

Ilmselt on nimisõnade žanritundlik määr ja roll tekstis üldse sedavõrd olulised, et nominaalsus kui temaatiliselt tingitud kvalitatiivne nähtus vajaks põhjalikumat uurimist mahukas ja esinduslikus žanrikorpuses.

${ }^{68}$ Seal, kus on olnud kasutada 28 žanri võrdlusandmed (formaalsus, nominaalsus ja leksikaalne tihedus), peaks 95\% ulatuses (usaldusnivool 0,5) olulised olema kõik korrelatsioonikordajad r, mis on üle kriitilise väärtuse 0,38 . 
Kõige raskem on tõlgendada teksti raskusastme (Lix) seoseid muude parameetritega. Lixi sai ühtlasi suhestada väga kitsas valimis (Avita uuemad õpikud ning väike värske ajakirjandus- ja teadustekstide valim), peale õpikute polnud varasemast võtta Lixi andmeid. Ebaoluline seos $(r=0,211)$ teksti Lixi ja leksikaalse tiheduse vahel paneb oletama, et raskusaste on tehnilisem mõiste kui jälgitavus muus mõttes (tuleme selle juurde allpool tagasi). Väheoluline seos ilmnes Lixil ka formaalsusega $(r=0,350)$, tugev seos aga nominaalsusega $(r=0,788)$, mis näitab $\mathrm{u}$ 60 -protsendilist vastastikust mõju. Olulisi seoseid leidus veelgi, kuid materjali ühekülgsuse ja võrdlusvõimaluste nappuse tõttu vajavad need aga märksa ulatuslikuma ja mitmekesisema materjali uurimist, enne kui usutavaid tõlgendusi pakkuda.

Seejuures väärib tähelepanu, et ühesugune raskusaste ilmnes laiale lugejaskonnale vastuvõetavatel tabloididel ja siin uuritud ebatavaliselt pika lausega teadustekstivalimil. Ei saa kuidagi arvata, et teadustekst oleks niisama laialt vastuvõetav kui suure loetavusega ajalehed. See juhib ühest küljest taas tähelepanu nii leksika ulatusele (vt Pajupuu jt 2010) ja eripärale (sealhulgas Jaan Miku arutlused sõnavara abstraktsusastme üle) kui ka sõnaliikide tasakaalule ja määrale tekstis (mida siin ka mõõdeti). Teisest küljest võib see juhuslik tõik osutada, et valim oli liiga väike või et tasakaalustatud korpus ei anna toimivast keelest usaldusväärset pilti, nagu on väitnud Mike Nelson (2000).

Vahest kasvab arusaamine teksti keerukusest ja arusaadavusest paremini, kui arendada detailsemalt ja enamate žanrite toel Bloori (2004) üsna usutavat hüpoteesi teksti aeglasest ja kiirest kulust, mis andis teatava eelise pikkadele lausetele (vt ülal arutlust Lixi üle). Lause pikkus ja verbilisus on näiteks samasuunalised, ehkki korrelatsioon on nõrgapoolne $(r=0,382)$. Uuritud tekst on ühtlasi - kuigi niisama nõrgalt - aeglasem ehk vähem kiire, kui tegusõnu on rohkem $(r=-0,393)$ või nimisõnu vähem $(r=0,453)$. Need seosed on küll olulised, kuid vaadeldud ebausaldusväärselt väikses valimis.

Küsimus on, kas siin uurimiseks valitud muutujad on piisavalt kõnekad. Ilmselgelt vajab lause pikkuse mõõtmise kõrval tähelepanu teksti ja selle osade (lõikude, lausete) kompositsioon ning seostamine - seda nii kvalitatiivse sõnastusuurimusena kui ka üldistava žanriuurimusena (vt ka allpool). Ka on selged viiteahelad ja muu sõnaselgete sidusvahendite kasutamine mõtteseoste jälgitavuse olulised tegurid, kuid hetkel täiesti 
tähelepanu alt väljas. Kolme statistilist suundumust soovitab edaspidi kontrollida Sandra Harrisoni ja Paul Bakkeri (1998) ingliskeelsete tekstide jälgitavuse ja keerukuse alustav uurimus. See väärib diskussiooni.

Esiteks on leksikaalne tihedus nende järgi parem jälgitavuse indikaator kui raskusastmearvutused millise tahes valemiga. Siinne uurimus toetab nende seisukohta kaudselt sellega, et Lix ja LD väheses uuritud materjalis omavahel oluliselt ei seostu (vt ülal). Õpivara kontekstis tuleb aga neile ka vastu vaielda: õpiku jälgitavuse eri parameetreid peab mõtestama eakohaselt. Esimeses ja osati ka teises kooliastmes on ilmselt vägagi oluline teksti raskusaste kui lugemistehnika astmelist arengut arvestav muutuja. Kuigi teksti paras tihedus on sisu omandamiseks olulisem, käib eakohatult raskes tekstis mõttekulu jälgimine ja esmane üldjoontes arusaamine üle jõu. Ka tuleb arvestada, et leksikaalne tihedus on võrdlemisi tugevas korrelatsioonis sõnavara rikkusega $(r=0,723)$, lapse sõnavara on aga suhteliselt ahas (vt ja vrd Karlep 1998: 276; Leiwo 1993: 98). Tehnilist raskust mahendab samas igasuguste tekstiüksuste korduvus ja tuttavlikkus. See nõuab, et arvestataks nii kindlate sõnade sagedust kui ka sõnavara ulatust (tekstisõnade jaotust mingite kontekstide kasutussageduse järkude vahel). Järeldub, et õpikute uurimiseks ja hindamiseks on vaja nii uutel alustel sagedussõnastikke (ja õpilaste sõnavara ulatuse uurimusi) kui ka žanrikohaste lekseemikimpude ehk korduvate kollokatsioonide loendeid.

Teiseks tõdevad Harrison ja Bakker (1998), et lause liigendus on niisama oluline tekstikeerukuse mõjutaja kui lause pikkus. Ülal esitatud arutlused sunnivad seda tähelepanekut tõsiselt võtma. Uurimata on nt õpiteksti osalausete, kuid ka lühikeste lausete seostamise viis: kaks lauset võivad anda edasi sama mida liitlause, kuid viimases on tavaliselt selge tähendusega sidend ja lugeja peab ise vähem seoseid järeldama. Süntaksi arvestamine nõuab küll juba märksa keerukamaid meetodeid kui autorid ja kirjastajad saaks igapäevaselt kasutada, kuid keeletehnoloogia arenedes tasub sedagi vajadust silmas pidada.

Kolmandaks ütlevad viidatud, et keskmistega võrdlemise kõrval tuleks arvesse võtta ka muutujate distributsiooni ja sagedasimaid väärtusi. (Vt kõiki üldistusi ja rakendussoovitusi Harrison, Bakker 1998: 133-137.) Kõike seda on mingil määral ja kaudselt ka ülal püütud teha, kuid seegi on optimaalselt võimalik esinduslike mahukate täistekstikorpuste olemasolul.

Teisalt määrab teksti vastuvõtu edukuse kõige enam huvi. Sagedussõnastike ja lekseemikimpude ea- ja žanrikohane arvesse võtmine, teksti- 
keerukuse täpsem arvestamine jms tagaks küll tekstis pakutud teadmiste ja eelteadmiste (maailmapildi) kooskõla, kuid A. de Beaugrande'i ja W. Dressleri arvates ei saagi jälgitavust sellist kooskõla taotledes optimeerida - teksti informatiivsus kannataks ja huvi kaoks. Tähtis on hoopis õige proportsioon lugemiseks vajamineva pingutuse ja sellest tekkiva taipamise vahel (Beaugrande, Dressler 1981/2002: X). Ka kirjaoskuse metakognitsiooni uurijad rõhutavad, et huvitav on õpilase jaoks see, mis väärtuslik, st kogemusega haakuv, kuid samas ootamatu. Teisalt aga on ka see tõestatud, et huvi kahandavad muu hulgas teksti kiirus ja pikad sõnad. (Griffith, Ruan 2005: 9) Nii jääb alati väga palju õpiku tõhususest autori ja toimetaja intuitsiooni varale, sest õpieduks vajalik pingutus ja taipamisest tekkiv rõõm on mingites eakohastes piirides individuaalne.

Nõnda tuleb tõdeda, et õpikukvaliteedi jaoks imerohtu ei ole. Ühest küljest on meie tekstikorpuste areng koos keeletehnoloogiliste võimaluste pideva ja loomuliku kasvuga õpikukvaliteedi arendamise võti. Teisest küljest tundub see, mida intuitiivselt teha saab, olevat uuritud kirjastusel praeguseks juba suuresti tehtud. Mööndusi muidugi on. Näiteks jääb 7. klassi raske muusikaõpiku rakendusviis ja omandatu tagasiside kooli õppekava ja õpetaja nõudmiste varale; eespool märgiti ka 5. klassi ajalooõpiku autoristiili teatavat probleemsust.

Kui ilmnevad uued keeletehnoloogiliselt toetatud toimetamisvõimalused, siis on õhus küsimus, kus neid rakendada - üsna ilmselt kolib õppimine praegusest enam internetti ja õpikud hakkavad sinna suunama (millega tahes õpilane sinna moodsal ajal ligi pääseks). Nii saavad õpikud uue parameetri ja veebiharjumused tulevikus täiskasvanulikuma, enam juhendatud orientatsiooni (vt Puksand 2010b, 2011, 2012 ilmumas). Tekstimuutujaid tuleb aga rohkem või vähem intuitiivselt arvestada keelekasutuse kanalist sõltumata, seostades neid ühtaegu nii noorte enda eakohaste võimete ja tekstiharjumuste kui ka nende tulevaste, täiskasvanuelu vajadustega.

\section{Materjali allikad (klasside ja ilmumisaja järjestuses)}

\section{Ajalugu}

Hergauk, Eha, Mart Laar, Maria Tilk 2002. Ajalugu 5. klassile. Tallinn: Avita. Vseviov, David 2002. Pilk ajalukku. 5. klassi õpik. Tallinn: Koolibri.

Piir, Milvi Martina 2009. Inimesed ajas. Ajalooõpik 5. klassile. I osa. Tallinn: Avita. 
Piir, Milvi Martina 2009. Inimesed ajas. Ajalooõpik 5. klassile. II osa. Tallinn: Avita.

Kõiv, Mait, Milvi Martina Piir 2010. Vanaaeg. Ajalooõpik 6. klassile. I osa. Tallinn: Avita.

Kõiv, Mait, Milvi Martina Piir 2010. Vanaaeg. Ajalooõpik 6. klassile. II osa. Tallinn: Avita.

\section{Emakeel}

Hiisjärv, Piret 2001. Õpime eesti keelt suheldes. Eesti keele õpik 4. klassile. Tallinn: Avita.

Maanso, Viivi, Kaider Vardja, Merike Vardja 2001. Emakeele ABC. IV klassi õpik. Tallinn: Koolibri.

Hiisjärv, Piret 2002. Õpime eesti keelt suheldes. Eesti keele õpik 5. klassile. Tallinn: Avita.

Maanso, Viivi, Kaider Vardja, Merike Vardja 2002. Sõnasõber. V klassi eesti keele õpik. Tallinn: Koolibri.

Hiisjärv, Piret 1999. Eesti keele õpik 6. klassile. Tallinn: Avita.

Maanso, Viivi, Kaider Vardja, Merike Vardja 1999. Keelesõber. VI klassi emakeeleõpik. Tallinn: Koolibri.

\section{Loodusõpetus}

Kaljula, Sirje, Aivo Saar 2001. Loodusõpetus IV klassile. 1. osa. Tallinn: Koolibri.

Kaljula, Sirje, Hergi Karik, Aivo Saar, Kalle Sirel 1998. Loodusõpetus V klassile. Tallinn: Koolibri.

Relve, Hendrik 1999. Loodusõpetus VI klassile. 1. osa. Tallinn: Koolibri.

Relve, Hendrik 1999. Loodusõpetus VI klassile. 2. osa. Tallinn: Koolibri.

\section{Muusikaõpetus}

Pullerits, Monika, Liivi Urbel 2010. Muusikaõpik 4. klassile. Tallinn: Avita.

Pullerits, Monika, Liivi Urbel 2010. Muusikaõpetuse töövihik 4. klassile. Tallinn: Avita.

Sepp, Anu, Aive Skuin, Karolina Sepp 2007. Muusikaõpik. 7. klass. Tallinn: Avita.

Sepp, Anu, Aive Skuin, Karolina Sepp 2007. Muusikaõpetuse töövihik. 7. klass. Tallinn: Avita. 


\section{Kirjandus}

Aava, Kartin 2011. Teadmuspõhise ühiskonna ja elukestva õppe diskursuste rekontekstualiseerimine Eestis. - Eesti Rakenduslingvistika Ühingu aastaraamat 7. Toim. Helle Metslang, Margit Langemets, Maria-Maren Sepper. Tallinn, 5-18. http://dx.doi.org/10.5128/ERYa7.01.

Annus, Anneliis 2011. Õpikukeele analüüs VI klassi „Vanaaja” näitel. Bakalaureusetöö. Tallinn: Tallinna Ülikooli eesti keele ja kultuuri instituut.

Antia, Bassey Edem 2000. Terminology and Language Planning. An Alternative Framework of Practice and Discourse. (= Terminology and Lexicography Research and Practice 2.) Amsterdam, Philadelphia: John Benjamins.

Argus, Reili 2011. Kui hea on meie kooliõpikute eesti keel? - Õpetajate Leht 11.02.2011.

Beaugrande, Robert-Alain de, Wolfgang Ulrich Dressler 1981. Einführung in die Textlinguistik. (= Konzepte der Sprach- und Literaturwissenschaft 28.) Tübingen: Niemeyer $=[$ Digitalized version $]$ 2002. Introduction to Text Linguistics; http://www.beaugrande.com/introduction_to_text_linguistics.htm (20.01.2012). http://dx.doi.org/10.1515/9783111349305.

Biber, Douglas 1995. Dimensions of Register Variation. A Cross-Linguistic Comparison. Cambridge, New York: Cambridge University Press. http:// dx.doi.org/10.1017/CBO9780511519871.

Björnsson, Carl-Hugo 1968. Läsbarhet. Stockholm: Almqvist och Wiksell.

Björnsson, Carl-Hugo 1969. Lix på Danska. Stockholm: Pedagogiskt centrum, Stockholms skolförvaltning.

Bloor, Meriel 2004. Towards a systemic functional model forcomparing forms of discourse in academic writing. - Ilha do Desterro. Journal of English Language, Literatures in English and Cultural Studies. Revista de Língua Inglesa, Literaturas em Inglês e Estudos Culturais. Vol. 46: Special Issue on Systemic Functional Linguistics in Action, 83-115.

Crawford Camiciottoli, Belinda 2007. The Language of Business Studies Lectures. A corpus-assisted analysis. Amsterdam: John Benjamins Publishing Company.

DuBay, William H. 2004. The Principles of Readability. Costa Mesa, California: Impact Information.

Elts, Jaanus 1995. Word length and its semantic complexity. - Family and Textbooks. Ed. Inger Kraav, Jaan Mikk, Larissa Vassiltchenko. (= Proceedings of the Department Education 3.) Tartu: Tartu Ülikool.

Erelt, Tiiu 2007. Leksikoloogia. - Mati Erelt, Tiiu Erelt, Kristiina Ross. Eesti keele käsiraamat. Kolmas, täiendatud trükk. Tallinn: Eesti Keele Sihtasutus, 587-703.

Fairclough, Norman 2010. Analysing Discourse. Textual analysis for social research. London, New York: Routledge. 
Gee, James Paul 2004. Situated Language and Learning. London, New York: Routledge.

Gee, James Paul 2008. An Introduction to Discourse Analysis. Theory and method. $2^{\text {nd }}$ edition. New York, London: Routledge.

Griffith, Pricilla E., Jiening Ruan 2005. What is metacognition and what sould be its role in literacy instruction? - Metacognition in Literacy Learning. Theory, Assessment, Instruction, and Professional Development. Ed. Susan E. Israel, Cathy Collins Block, Kathryn L. Bauserman, Kathryn Kinnucan-Welsch. Mahwah (NJ), London: Lawrence Erlbaum, 3-18.

Hakulinen, Auli 1993. Mitä ihminen äidinkielestään tietää? Luento Suomalaisen mieli ja kieli -symposiumissa. - Virke 1. Helsinki: Äidinkielen Opettajain Liitto, 10-14.

Halliday, Michael A. K. 1989. Spoken and Written Language. Oxford: Oxford University Press.

Halliday, Michael A. K. 1994. An Introduction to Functional Grammar. Second Edition. London: Edward Arnold.

Harrison, Colin 1980. Readability in the Classroom. Cambridge University Press.

Harrison, Sandra, Paul Bakker 1998. Two new readability predictors for the professional writer: pilot trials. - Journal of Research in Reading 21 (2), 121-138. http://dx.doi.org/10.1111/1467-9817.00049.

Henno, Imbi (koost.) 2011. Õpiraskustega õpilase toetamine põhikoolis (ainealased metoodilised ja õppematerjalid). Tallinn, Tartu: Ristiku Põhikool, Haridus- ja Teadusministeerium. (Vt www.oppekava.ee rubriigist „Abiks õpetajale".)

Heylighen, Francis, Jean-Marc Dewaele 2002. Variation in the contextuality of language: An empirical measure. - Foundation of Science 7, 293-340.

IRA 1999 = David W. Moore, Thomas W. Bean, Deanna Birdyshaw, James A. Rycik 1999. Adolescent Literacy. A position statement for the Commission on Adolescent Literacy of the International Reading Association; http://www.reading.org/resources/issues/positions_adolescent.html (24.03.2007).

Israel jt 2005 = Susan E. Israel, Cathy Collins Block, Kathryn L. Bauserman, Kathryn Kinnucan-Welsch (ed.). Metacognition in Literacy Learning. Theory, Assessment, Instruction, and Professional Development. Mahwah (NJ), London: Lawrence Erlbaum.

Jacobsen Khan, Eiliyah Julie 2010. Afkompicering af juridisk sprog. Resumé: Simplifying legal language. Frederiksberg: Institut for Internationale Sprogstudier og Vidensteknologi, 19-21.

Johnson, David, Gunther Kress 2003. Globalisation, Literacy and Society: redesigning pedagogy and assessment. - Assessment in Education 10 (1), 5-14. http://dx.doi.org/10.1080/09695940301697. 
Kaalep, Heiki-Jaan, Muischnek, Kadri 2002. Eesti kirjakeele sagedussõnastik. Tartu.

Karlep, Karl 1998. Psühholingvistika ja emakeeleõpetus. Tartu: Tartu Ülikooli Kirjastus.

Karvonen, Pirjo 1995. Oppikirjateksti toimintana. Helsinki: Suomalaisen Kirjallisuuden Seura.

Kasik, Reet 2007. Sissejuhatus tekstiõpetusse. Tartu: Tartu Ülikooli Kirjastus.

Kerge, Krista 2000. Kirjakeel ja igapäevakeel. - Eesti keele allkeeled. Toim. Tiit Hennoste. (= Tartu Ülikooli eesti keele õppetooli toimetised 16.) Tartu: Tartu Ülikooli Kirjastus, 75-110.

Kerge, Krista 2002a. Kirjakeele kasutusvaldkondade süntaktiline keerukus. Tekstid ja taustad. Artikleid tekstianalüüsist. Toim. Reet Kasik. (= Tartu Ülikooli eesti keele õppetooli toimetised 23.) Tartu: Tartu Ülikooli Kirjastus, 29-46.

Kerge, Krista 2002b. Varieties of language and mother tongue teaching orientation. - Learning and Educational Media. Ed. Jaan Mikk, Veijo Meisalo, Hasso Kukemelk, Mike Horsley. [= The Third IARTEM Volume.] Tartu: The International Association for Research on Textbooks and Educational Media, University of Tartu, 230-236.

Kerge, Krista 2003. Keele variatiivsus ja mine-tuletus allkeelte süntaktilise keerukuse tegurina. (= Tallinna Pedagoogikaülikooli humanitaarteaduste dissertatsioonid 10.) Tallinn: Tallinna Pedagoogikaülikooli kirjastus.

Kerge, Krista 2008a. Tekstitöö ja vahendusoskus. - Iseseisev keelekasutaja. B1- ja B2-taseme eesti keele oskus. Koost. Anu-Reet Hausenberg, Marju Ilves, Anne-Katrin Kaivapalu, Krista Kerge, Katrin Kern, Mare Kitsnik, Ingrid Krall, Karin Rummo, Tiina Rüütmaa. Tartu: Atlex; [Tallinn:] Riiklik Eksami- ja Kvalifikatsioonikeskus, 121-139.

Kerge, Krista 2008b. Vilunud keelekasutaja. C1-taseme eesti keele oskus. Tallinn: Eesti Keele Sihtasutus.

Kerge, Krista 2010a. Kirjažanrite keeleparameetrid mitme tekstiliigi taustal. Emakeele Seltsi aastaraamat 55 (2009). Peatoim. Mati Erelt. Tallinn: Teaduste Akadeemia Kirjastus, 32-62.

Kerge, Krista 2010b. Tekstikeskne keeleõpetus põhikoolis. - Põhikooli valdkonnaraamat „Eesti keel ja kirjandus”. Koost. Mari Kadakas. Tallinn: Riiklik Eksami- ja Kvalifikatsioonikeskus; http://www.oppekava.ee, link 15 (25.01.2012).

Kerge, Krista 2011a. Tekst gümnaasiumi emakeeleõpetuse keskmes. - Gümnaasiumi valdkonnaraamat „Eesti keel ja kirjandus”. Koost. Mari Kadakas. Tallinn: Riiklik Eksami- ja Kvalifikatsioonikeskus; http://www.oppekava. ee, link 12 (20.02.2012).

Kerge, Krista 2011b. Tekstitoimingute valdamine. - Gümnaasiumi valdkonnaraamat „Eesti keel ja kirjandus”. Koost. Mari Kadakas. Tallinn: Riiklik 
Eksami- ja Kvalifikatsioonikeskus; http://www.oppekava.ee, link 14 (20.02.2012).

Kerge, Krista 2011c. Keeleõppe sotsiokognitiivsest paradigmast. - Gümnaasiumi valdkonnaraamat „Eesti keel ja kirjandus”. Koost. Mari Kadakas. Tallinn: Riiklik Eksami- ja Kvalifikatsioonikeskus; http//:www.oppekava.ee, link 15 (20.02.2012).

Kerge, Krista, Anne Uusen 2010. Toimingu- ja tekstikeskne keelemaailm. Tekstid ja taustad VI. Tekstiuurimus ja kool. Toim. K. Kerge. (= Eesti keele ruum. Emakeeleõpetuse Infokeskuse toimetised 5.) Tallinn: Tallinna Ülikool, 95-111.

Kerge, Krista, Hille Pajupuu 2010. Text-types in speech technology and language teaching. - Analysing Data $>$ Describing Variation. Proceedings of the XXVIII International Conference of AESLA. Ed. Jorge Luis Bueno Alonso, Dolores González Álvarez, Úrsula Kirsten Torrado, Ana E. Martínez Insua, Javier Pérez Guerra, Esperanza Rama Martínez \& Rosalía Rodríguez Vázquez. Vigo: Universidade de Vigo (Servizo de Publicacións), 380-390.

Kerge jt 2007 = Krista Kerge, Hille Pajupuu, Rene Altrov. Tekst, kontekstuaalsus ja kultuur. - Keel ja Kirjandus 8, 624-637.

Kern, Richard 2000. Literacy and Language Teaching. Oxford: Oxford University Press.

Leiwo, Matti 1993. Lapse keeleline areng. Tallinn: Tallinna Pedagoogikaülikool. Levy, Stacia 2008. Lexical Bundles in Professional and Student Writing. A Study in Linguistic Variation. Saarbrücken: VDM Verlag Dr Müller.

Maanso, Viivi 1979. Võõrsõnatarvitusest keskastme õpikuis. - Õppeteksti ja õpilaste väljendusoskuse probleeme. Koost. Endel Noor. Toim. Viivi Maanso, Jaan Mikk. Pedagoogikateaduselt koolile. Eesti NSV Pedagoogiline Teadusliku Uurimise Instituut, Eesti NSV Pedagoogilise Uurimistöö Koordineerimise Nõukogu. Tallinn: Eesti NSV Pedagoogiline Teadusliku Uurimise Instituut, 42-60.

Maanso, Viivi 1981. Üldhariduskooli õpikute sõnavarast. - Pedagoogiliste uurimuste tulemused 1976-1980. Keel ja Kool. Koost. Endel Noor. Eesti NSV Pedagoogika Teadusliku Uurimise Instituut, Eesti NSV Pedagoogilise Uurimistöö Koordineerimisnõukogu. Tallinn: Eesti NSV Haridusministeerium, 4-14.

Maanso, Viivi 1982. Meie õpikute keelest: sõnapikkusest ja selle vastavusest õpilaste lugemisoskuse tasemele. - Nõukogude Kool 1, 24-26.

Maanso, Viivi, Jaan Mikk (toim.) 1979. Õppeteksti ja õpilaste väljendusoskuse probleeme. Koost. Endel Noor. Pedagoogikateaduselt koolile. Eesti NSV Pedagoogiline Teadusliku Uurimise Instituut, Eesti NSV Pedagoogilise Uurimistöö Koordineerimise Nõukogu. Tallinn: Eesti NSV Pedagoogiline Teadusliku Uurimise Instituut. 
Meier, Heidi 2003. Essee asend allkeelte tekstitüübivõrdluses. Magistritöö. Käsikiri Tallinna Ülikooli eesti keele ja kultuuri instituudis. Tallinn: Tallinna Pedagoogikaülikool.

Mikk, Jaan 1979. Õppeteksti keerukus ja õpilaste väljendusoskus. - Õppeteksti ja õpilaste väljendusoskuse probleeme. Koost. Endel Noor. Toim. Viivi Maanso, Jaan Mikk. Pedagoogikateaduselt koolile. Eesti NSV Pedagoogiline Teadusliku Uurimise Instituut, Eesti NSV Pedagoogilise Uurimistöö Koordineerimise Nõukogu. Tallinn: Eesti NSV Pedagoogiline Teadusliku Uurimise Instituut, 7-12.

Mikk, Jaan 1980. Teksti mõistmine. Tallinn: Valgus.

Mikk, Jaan 1991. Didaktika küsimusi. Loengukonspekt üliõpilasele. Tartu: Tartu Ülikool.

Mikk, Jaan 2000. Textbook: Research and Writing. Frankfurt am Main: Peter Lang.

Mikk, Jaan 2003. Kuidas hinnata õppeteksti keerukust? - Õpetajate Leht 01.08.2003.

Mikk, Jaan, Heli Uibo, Jaanus Elts 2001. Word length as an indicator of semantic complexity. - Text as a Linguistic Paradigm: Levels, Constituents, Constructs. Festschrift in Honour of Luděk Hřebíček. Ed. Ludmila Uhlířová, Gejza Wimmer, Gabriel Altmann, Reinhard Köhler. Trier: Wissenschaftlicher Verlag Trier, 187-195.

Mägedi, Merike 2003. Sõnavara võõrus. Võõrsõnad eesti tekstis. Magistritöö. Käsikiri Tallinna Ülikooli eesti keele ja kultuuri instituudis. Tallinn: Tallinna Pedagoogikaülikool.

Nelson, Mike 2000. Chapter 5. The Methodological Background: British Traditions of Text Analysis, Correlative Register Analysis and Corpus Linguistics. - A Corpus-Based Study of Business English and Business English Teaching Materials. PhD Thesis. Ms. Manchester: University of Manchester; http://users.utu.fi/micnel/thesis/Chapter5\%20.html.

Nevins, M. Eleanor 2010. Intertextuality and misunderstanding. - Language \& Communication 30 (1). Intertextuality and Misunderstanding, 1-6. http:// dx.doi.org/10.1016/j.langcom.2009.10.001.

Niglas, Katrin 1997. Statistika loengumaterjale. Tallinn: Tallinna Pedagoogikaülikooli informaatika osakond.

Ochs, Elinor 1993. Constructing social indentity: A language socialization perspective. - Research on Language and Social Interaction 26 (3), 278-306.

Pajupuu jt 2009 = Hille Pajupuu, Krista Kerge, Pilvi Alp. Sõnavara loomulik rikkus haritud keeleoskaja tekstides. - Eesti Rakenduslingvistika Ühingu aastaraamat 5. Toim. Helle Metslang, Margit Langemets, Maria-Maren Sepper; külalistoim. Reili Argus. Tallinn: Eesti Keele Sihtasutus, 187196. http://dx.doi.org/10.5128/ERYa5.12. 
Pajupuu jt 2010 = Hille Pajupuu, Krista Kerge, Lya Meister, Eva Liina Asu, Pilvi Alp. Naturalness of speaking and how to assess it. - Trames. Journal of the Humanities and Social Sciences 59 (2), 120-140. http://dx.doi. org/10.3176/tr.2010.2.02.

Pedley, Mel 2006. Designing for Dyslexics. The Art of Accessibility; http://accessites.org/site/2006/11/designing-for-dyslexics-part-3-of-3 (20.01.2012).

PISA 2009 = Helin Puksand, Tiit Lepmann, Imbi Henno 2010. PISA 2009 - Eesti tulemused. Eesti 15-aastaste õpilaste teadmised ja oskused funktsionaalses lugemises, matemaatikas ja loodusteadustes. Toim. Gunda Tire. Tartu: Haridus- ja Teadusministeerium.

Priimägi jt 1979 = Arne Priimägi, Jaan Mikk, Mai Nisamedtinova, Tiiu Voodla. Teksti mõistetavuse reeglite rakendamise efektiivsusest. - Õppeteksti ja õpilaste väljendusoskuse probleeme. Koost. Endel Noor. Toim. Viivi Maanso, Jaan Mikk. Pedagoogikateaduselt koolile. Eesti NSV Pedagoogiline Teadusliku Uurimise Instituut, Eesti NSV Pedagoogilise Uurimistöö Koordineerimise Nõukogu. Tallinn: Eesti NSV Pedagoogiline Teadusliku Uurimise Instituut, 16-36.

PRÕK 2011 = Põhikooli riiklik õppekava. Elektrooniline Riigi Teataja; https:// www.riigiteataja.ee/akt/13273133 (20.01.2012).

Puksand, Helin 2003. Sõnavara õpetamine ja õpikuteksti keerukus põhikooli II astme näiteil. Magistritöö. Käsikiri Tallinna Ülikooli eesti keele ja kultuuri instituudis. Tallinn: Tallinna Pedagoogikaülikool.

Puksand, Helin 2004. Loetavusindeksi Lix sobivusest eestikeelsele tekstile. Tekstid ja taustad III. Lingvistiline tekstianalüüs. Toim. Reet Kasik. (= Tartu Ülikooli eesti keele õppetooli toimetised 28.) Tartu: Tartu Ülikool, 108-119.

Puksand, Helin 2005. Terminoloogia õpikutes. - Tekstid ja taustad IV. Tekstiliigivaatlusi. Toim. Reet Kasik. (= Tartu Ülikooli eesti keele õppetooli toimetised 29.) Tartu: Tartu Ülikool, 68-81.

Puksand, Helin 2010a. Lugemine. Lugemis- ja õpiharjumused. - Helin Puksand, Tiit Lepmann, Imbi Henno. PISA 2009 - Eesti tulemused. Eesti 15-aastaste õpilaste teadmised ja oskused funktsionaalses lugemises, matemaatikas ja loodusteadustes. Toim. Gunda Tire. Tartu: Haridus- ja Teadusministeerium, 21-74.

Puksand, Helin 2010b. Tekstid, mida loevad teismelised. Teismeliste lugemisharjumuste kasutamine koolis. - Tekstid ja taustad VI. Tekstiuurimus ja kool. Toim. K. Kerge. (= Eesti keele ruum. Emakeeleõpetuse Infokeskuse toimetised 5.) Tallinn: Tallinna Ülikool, 20-35.

Puksand, Helin 2010c. Meetodeid teksti mõistmise arendamiseks. - Põhikooli valdkonnaraamat „Eesti keel ja kirjandus”. Koost. Mari Kadakas. Tallinn: Riiklik Eksami- ja Kvalifikatsioonikeskus. Tallinn: REKK; http://www. oppekava.ee/, link 13 (25.01.2012). 
Puksand, Helin 2011. Eesti koolinoorte lugemisharjumused meedia näitel. Eesti Rakenduslingvistika Ühingu aastaraamat 7. Toim. Helle Metslang, Margit Langemets, Maria-Maren Sepper. Tallinn, 179-195. http://dx.doi. org/10.5128/ERYa7.11.

Puksand, Helin 2012 (ilmumas). Reading habits of the Estonian adolescents the basis for lifelong learning. - Lifelong Learning. Ed. Jaan Mikk. Frankfurt am Main: Peter Lang.

Põld, Karin 2008. Jaan Kaplinski tekstide kontekstuaalsus ja süntaks. Bakalaureusetöö. Tallinn: Tallinna Ülikooli eesti keele ja kultuuri instituut.

Raik, Margit 2001. Võõrsõnad põhikooli emakeele- ja kirjandusõpikutes. Bakalaureusetöö. Käsikiri Tallinna Ülikooli eesti keele ja kultuuri instituudis. Tallinn: Tallinna Pedagoogikaülikool.

Rayner jt 2001 = Keith Rayner, Barbara R. Foorman, Charles A. Perfetti, David Pesetsky, Mark S. Seidenberg. How psychological science informs the teaching of reading. - Psychological Science in the Public Interest 2 (2), 31-74. http://dx.doi.org/10.1111/1529-1006.00004.

Reid, Ian (ed.) 1987. The Place of Genre in Learning. Deakin: Deakin University Press.

Stubbs, Michael 1996. Text and Corpus Analysis. Oxford, England \& Cambridge, USA: Blackwell.

Urbel, Liivi 2010. Ainekavas taotletavad õpitulemused, õppesisu ja õppetegevus (õppeprotsessi kirjeldus). Sissejuhatus. - Põhikooli valdkonnaraamat „Kunstid”: Muusika. Tallinn: REKK, 1-6; http://www.oppekava.ee/index.php/P\%C3\%B5hikooli_valdkonnaraamat_KUNSTID (21.01.2012).

Ure, Jean 1971. Lexical density and register differentiation. - Applications of Linguistics. Ed. G. Perren, J. L. M. Trim. London: Cambridge University Press, 443-452.

Vermeer, Anne 2000. Coming to grips with lexical richness in spontaneous speech data. - Language Testing 17 (1), 65-68. http://dx.doi. org/10.1191/026553200676636328. 


\title{
Analysis of learning texts in the context of literacy acquisition
}

\author{
Helin Puksand, Krista Kerge
}

On the background of literacy theory (e.g. Gee 2004, 2008), as well as research on the Estonian learning media (e.g. Mikk 2000) and genres (Kerge, Pajupuu 2010 on 18 written and 10 oral genres), this article deals with the text parameters of four textbooks (music for grades 4 and 7, plus history for grades 5 and 6). Learning texts were studied for their readability, exactness, and lexical parameters: (1) text difficulty measured with Lix (Björnsson 1968), (2) nominality (proportion of nouns) and (3) lexical density measured by the Ure-formula (see Halliday 1989, 1994 for both); (4) formality index F pointing to the level of ambiguity and thus to wording exactness (Heylighen and Dewaele 2002 formula); (5) lexical richness (Uber-index; see Vermeer 2000), and (6) lexical qualities (representation of special terms, percentage of loan words of foreign structure, recurrence of lexemes). For index Lix and its factors, 11 more textbooks of natural studies, mother tongue, and history for grades 4-6 were compared (based on Puksand 2003) to those mentioned above. Some visual observations were made to interpret the statistical data in the light of legibility (e.g. lay-out features such as text, paragraph and line length, use of illustrations, etc.

Quantitative results put texts situated in learning process of the age group from 10 to 13 years on the continuous scales of Estonian genres in general. This made it possible to evaluate the appropriateness of the text for the relevant age group: there were problems with two recent textbooks (history for grade 5 and music for grade 7) showing a level higher than the median of the Estonian adult written genres. On the other hand, one of the difficult textbooks was quite easy by its lexis while the other one was extremely hard to understand. As to the layout, both of them seemed appropriate even for those with learning difficulties. The correlations between the parameters made it possible to understand how to address a text in a more suitable for the age manner. For example, formality formula is based on the idea that nouns (referential units) make a text more exact than other parts of speech, but on the other hand, the more nominal units, the denser (and, thus, less understandable) a text is $(r=0.946)$. Writers and editors should provide sentential definitions rather than those in the form of lists, bracketed synonyms, hyponyms, or comments dominating now; they should enrich the text with more clarifications and examples, etc. To this end, a speed index as a quotient of LD per sentence was calculated (see Bloor 2004 on slow and fast texts). It showed that learning texts are faster than any adult genre except job-related electronic 
correspondence. Though, the text-speed phenomenon should be studied in a qualitative manner, and its measures need to be proved in a much wider range of situated genres. The latter applies to nominality and text difficulty, too (see also Harris and Bakker 1998).

Keywords: lexis of learning text, lexical richness, loan words with the foreign structure, nominal versus verbal style, readability, text difficulty, lexical density, fast and slow text, methodological problems of genre research, LSP and linguistic form of translated terms

\section{Helin Puksand}

kasvatusteaduste instituut

Tallinna Ülikool

Narva mnt 25

10120 Tallinn

helin.puksand@tlu.ee

Krista Kerge

eesti keele ja kultuuri instituut

Tallinna Ülikool

Narva mnt 25

10120 Tallinn

krista.kerge@tlu.ee 